\title{
Identification and expression profiles of candidate chemosensory receptors in Histia rhodope (Lepidoptera: Zygaenidae)
}

\author{
Haibo Yang ${ }^{\text {Corresp., } 1}$, Junfeng Dong ${ }^{\text {Corresp., } 1}$, Ya-Lan Sun ${ }^{1}$, Zhenjie Hu ${ }^{1}$, Qihui Lv ${ }^{1}$, Dingxu Li ${ }^{1}$ \\ ${ }^{1}$ College of Forestry, Henan University of Science and Technology, Luoyang, Henan, China \\ Corresponding Authors: Haibo Yang, Junfeng Dong \\ Email address: hbyang@haust.edu.cn, junfengdong@haust.edu.cn
}

Insect olfaction and vision play important roles in survival and reproduction. Diurnal butterflies mainly rely on visual cues whereas nocturnal moths rely on olfactory signals to locate external resources. Histia rhodope Cramer (Lepidoptera: Zygaenidae) is an important pest of the landscape tree Bischofia polycarpa in China and other Southeast Asian regions. As a diurnal moth, $H$. rhodope represents a suitable model for studying the evolutionary shift from olfactory to visual communication. However, only a few chemosensory soluble proteins have been characterized and information on $\mathrm{H}$. rhodope chemoreceptor genes is currently lacking. In this study, we identified 45 odorant receptors (ORs), 9 ionotropic receptor s (IRs), 8 gustatory receptors (GRs) and 2 sensory neuron membrane proteins (SNMPs) from our previously acquired $H$. rhodope antennal transcriptomic data. The number of chemoreceptors of $H$. rhodope was less compared with that found in many nocturnal moths. Some specific chemoreceptors such as OR coreceptor (ORco), ionotropic receptor co-receptor, $\mathrm{CO}_{2}$ receptor, sugar receptors and bitter receptors were predicted by phylogenetic analysis. Notably, two candidate pheromone receptors (PRs) were identified within a novel PR lineage. qRT-PCR results showed that almost all tested genes (22/24) were predominantly expressed in antennae, indicating that they may be important in olfactory function. Among these antennae-enriched genes, 6 ORs, 5 IRs and 2 GRs displayed female-biased expression, while 2 ORs displayed malebiased expression. Additionally, HrholR75q.2 and HrhoGR67 were more highly expressed in heads and legs. This study enriches the olfactory gene inventory of $H$. rhodope and provides the foundation for further research of the chemoreception mechanism in diurnal moths. 
1

2 Identification and expression profiles of candidate

3 chemosensory receptors in Histia rhodope (Lepidoptera:

4 Zygaenidae)

5

6 7

Corresponding Author:

11 Hai-Bo Yang

12 Email address: hbyang@haust.edu.cn

13 Jun-Feng Dong

14 Email address: junfengdong@haust.edu.cn

25

26

27

28

29

30

31

32

33

34

35

36

37

38

39

40

41 


\section{Abstract}

43 Insect olfaction and vision play important roles in survival and reproduction. Diurnal butterflies

44

45

46

47

48

49

50

51

52

53

54

55

56

57

58

59

60

61

62

63

64

65

66

67

68

69

70

71

72

73

74

75

76

77

78

79

80

81

mainly rely on visual cues whereas nocturnal moths rely on olfactory signals to locate external resources. Histia rhodope Cramer (Lepidoptera: Zygaenidae) is an important pest of the landscape tree Bischofia polycarpa in China and other Southeast Asian regions. As a diurnal moth, $H$. rhodope represents a suitable model for studying the evolutionary shift from olfactory to visual communication. However, only a few chemosensory soluble proteins have been characterized and information on $H$. rhodope chemoreceptor genes is currently lacking. In this study, we identified 45 odorant receptors (ORs), 9 ionotropic receptors (IRs), 8 gustatory receptors (GRs) and 2 sensory neuron membrane proteins (SNMPs) from our previously acquired $H$. rhodope antennal transcriptomic data. The number of chemoreceptors of $H$. rhodope was less compared with that found in many nocturnal moths. Some specific chemoreceptors such as OR co-receptor (ORco), ionotropic receptor co-receptor, $\mathrm{CO}_{2}$ receptor, sugar receptors and bitter receptors were predicted by phylogenetic analysis. Notably, two candidate pheromone receptors (PRs) were identified within a novel PR lineage. qRT-PCR results showed that almost all tested genes $(22 / 24)$ were predominantly expressed in antennae, indicating that they may be important in olfactory function. Among these antennae-enriched genes, 6 ORs, 5 IRs and 2 GRs displayed female-biased expression, while 2 ORs displayed male-biased expression. Additionally, HrhoIR75q.2 and HrhoGR67 were more highly expressed in heads and legs. This study enriches the olfactory gene inventory of $H$. rhodope and provides the foundation for further research of the chemoreception mechanism in diurnal moths.

\section{Introduction}

Histia rhodope Cramer (Lepidoptera: Zygaenidae), a diurnal moth, is a destructive forest pest widely distributed in China and other Southeast Asian regions (Huang, 1980). Although $H$. rhodope is an oligophagous pest, its larvae mainly feed on the leaves of Bischofia polycarpa (Chinese bishopwood), resulting in severe defoliation. Mature larvae always fall from the tree by spinning silk, which not only affects the appearance but also disturbs human activities (Huang, 1980; Yang et al., 2019). Upon eclosion, males court females through nuptial flight in the afternoon. In addition, females release sex pheromones for attracting males. After mating, females then search for suitable oviposition sites and lay eggs (Yang et al., 2019). Therefore, the detection of sex pheromones is crucially important for reproduction.

Olfaction plays an important role in many behaviors in insects. Insects depend on their sensitive olfactory system to detect semiochemicals in complex environments (Gadenne, Barrozo \& Anton, 2016; Haverkamp, Hansson \& Knaden, 2018). A myriad of proteins is implicated in the process of olfactory perception. Chemoreceptors are key proteins that interact directly with odorants and play an important role in the specificity and sensitivity of insect peripheral chemoreception (Leal, 2013). Chemosensory receptors include odorant receptors (ORs) (Clyne et al., 1999), gustatory receptors (GRs) (Agnihotri, Roy \& Joshi, 2016) and ionotropic receptors (IRs) (Benton et al., 2009). Additionally, sensory neuron membrane proteins (SNMPs), located

Peer) reviewing PDF | (2020:05:48878:1:2:NEW 21 Aug 2020) 
82 in different dendrites of the olfactory receptor neurons, function in odor detection (Rogers, 83 Krieger \& Vogt, 2001).

84 Insect ORs were first identified in the Drosophila melanogaster genome. They are

85 characterized by seven transmembrane domains (TMDs) with an intracellular N-terminus and an 86 extracellular C-terminus (Clyen et al., 1999). During chemosensory signal transduction, ORs 87 serve as signal-transducers by converting chemical signals into electric signals in the insect 88 olfactory process (Hallem \& Carlson, 2006). Functional insect ORs consist of a ligand-gated

89

90

91

92

93

94

95

96

97

98

99

100

101

102

103

104

105

106

107

108

109

110

111

112

113

114

115

116

117

118

119

120

121

nonselective cation channel, composed of one divergent OR subunit that confers odor specificity, and one conserved OR co-receptor (ORco) subunit (Sato et al., 2008; Buttrerwick et al., 2018). The OR repertoire size is considerably variable among insect species, and the genes are rapidly evolving (Andersson, Löfstedt \& Newcomb, 2015; Robertson, 2019).

IRs belong to the ionotropic glutamate receptor family (iGluRs). Their molecular structures consist of an extracellular ligand-binding domain with two lobes and an ion channel (Benton et al. 2009). IRs can be divided into two subfamilies: conserved 'antennal IRs', involved in olfaction, thermo- and hygrosensation, and species-specific 'divergent IRs', found in peripheral and internal gustatory organs and involved in gustation (Croset et al., 2010; Koh et al., 2014). Similar to ORco, IRs have highly conserved IR co-receptors in different insect species, including IR8a, IR25a and IR76b, which are widely expressed and play different roles in the process of odorant and taste sensation (Abuin et al., 2011). Besides the perception of acids, amines and amino acids (Hussain et al., 2016), IRs are also involved in sensing temperature and humidity stimuli, auditory function and regulating the circadian clock (Senthilan et al., 2012; Chen et al., 2015; Ni et al., 2016; Frank et al., 2017). To date, IRs function reported in lepidopteran species is quite limited. However, recent research showed that IR8a was essential for acid-mediated feces avoidance in ovipositioning hawkmoth, Manduca sexta (Zhang et al., 2019).

GRs and ORs have a similar membrane topology. GRs are mainly expressed in the gustatory organs (Dunipace et al., 2001; Touhara \& Vosshall, 2009; Guo et al., 2017), although some genes are also expressed in insect antennae (Croset et al., 2010). Generally, GRs are not highly conserved among insect species, and mainly detect some nonvolatile compounds and contact stimuli (Clyne, Warr \& Carlson, 2000; Scott et al., 2001). However, candidate carbon dioxide $\left(\mathrm{CO}_{2}\right)$ receptors are highly conserved in lepidopteran species, such as BmorGR 1-3 receptor from Bombyx mori (Wanner \& Robertson, 2008), HmelGR1-3 from Heliconius melpomene (Briscoe et al. 2013) and HarmGR1-3 from Helicoverpa armigera (Ning et al., 2016).

SNMPs belong to the cluster of differentiation 36 (CD36) receptor family with two TMDs and are mainly expressed in pheromone sensitive neurons in Drosophila and moths (Rogers, Krieger \& Vogt, 2001; Benton, Vannice \& Vosshall, 2007; Vogt et al., 2009). SNMPs are divided into SNMP1 and SNMP2 subgroups (Forstner et al., 2008). Notably, SNMPs are known to participate in pheromone detection (Jin, Ha \& Smith, 2008; Pregitzer et al., 2014; Sun et al., 2019), although the molecular mechanisms of their involvement in chemoreception are unknown.

Although various olfactory related genes have recently been identified in numerous moth species, most of them are from nocturnal moths, such as Noctuidae and Pyralidae (Yuvaraj et al.,

Peer) reviewing PDF | (2020:05:48878:1:2:NEW 21 Aug 2020) 
122

123

124

125

126

127

128

129

130

131

132

133

134

135

136

137

138

139

140

141

142

143

144

145

146

147

148

149

150

151

152

153

154

155

156

157

158

159

160

161

2018). However, some moth species are diurnal, such as Castniidae, Phaudidae, Sphingidae and Zygaenidae (Subchev, 2014; Monteys et al., 2016; Zheng et al., 2019; Chen et al., 2020). Their activities are only observed during the daytime. Studies investigating the chemosensory genes in diurnal moths are scarce. These genes have only been studied in one non-ditrysian moth, Eriocrania semipurpurella (Eriocraniidae), belonging to the oldest lineages of Lepidoptera (Yuvaraj et al., 2017). Visual and/or olfactory cues mediate the orientation of most lepidopteran adults during mating. The contrasting lifestyles between the diurnal and nocturnal insects result in a substantial distinction in their sensory biology: diurnal butterflies primarily rely on visual cues while nocturnal moths largely rely on olfactory signals (Martin et al., 2011; Arikawa, 2017). However, this does not imply that butterflies are anosmic or moths are blind. Both butterflies and moths employ olfactory signals for sex communication. Besides, even at night, male moths strongly rely on visual cues from the landscape to track a pheromone trail to find a receptive female (Preiss \& Kramer, 1986). While diurnal moths search for mating partners using olfactory cues over relatively long distances, they employ visual and auditory cues within short distances or even a combination of visual, olfactory and auditory signals (Chen et al., 2020).

Nevertheless, there has been a notable chemosensory/visual shift between moths and butterflies that at least affect long-range/short-range sex-attraction/courtship, as well as certain aspects of host plant recognition (Costanzo \& Monteiro, 2007). A previous study of gene gain and loss within the general odorant binding proteins (GOBP)/pheromone binding proteins (PBP) of two moths and butterflies revealed that diurnal butterflies might have lost a PBP gene compared with nocturnal moths (Vogt, Grosse-Wilde \& Zhou, 2015). Moreover, in our previous study, we constructed transcriptomes from both male and female adult antennae of $H$. rhodope using de novo transcriptome sequencing and assembly. We identified some chemosensory soluble proteins, such as odorant binding proteins (OBPs), chemosensory proteins (CSPs) and Niemann-Pick type $\mathrm{C} 2$ proteins (NPC2s) in this diurnal moth. We found that $H$. rhodope might also have lost a PBP gene (Yang et al., 2020). Therefore, we hypothesize that $H$. rhodope could also have lost chemoreceptor genes associated with moth pheromone detection. However, the numbers, expression profiles and functions of chemoreceptor genes in $H$. rhodope are unknown.

In the present study, we identified candidate chemoreceptor genes based on our previous antennal transcriptomic data of $H$. rhodope (Yang et al., 2020). The phylogenetic relationships between the ORs, IRs, GRs and SNMPs of H. rhodope and other insect species were further investigated. Finally, we examined their tissue expression using quantitative real-time PCR (qRT-PCR). This work provides the basis for future functional characterization of olfactory genes in $H$. rhodope.

\section{Materials \& Methods}

\section{Insect rearing and tissue collection}

H. rhodope was collected from B. polycarpa forest in Sui and Tang Dynasties City Ruins Botanical Garden $\left(112.45^{\circ} \mathrm{E}, 34.64^{\circ} \mathrm{N}\right)$ in Luoyang city, Henan province, China. We received verbal permission to collect insects in Sui and Tang Dynasties City Ruins Botanical Garden from 
162 the management of the Garden. The larvae were reared on fresh B. polycarpa leaves under

163

164

165

166

167

168

169

170

171

172

173

174

175

176

177

178

179

180

181

182

183

184

185

186

187

188

189

190

191

192

193

194

195

196

197

198

199

200

201

constant conditions of $25 \pm 1^{\circ} \mathrm{C}$ and $70 \pm 5 \%$ relative humidity with $16 \mathrm{~h}$ light: $8 \mathrm{~h}$ dark photoperiod. Adult moths were grouped based on their sex and fed with $10 \%$ honey solution after emergence. For RNA-seq samples, 500 pairs of 1 day old adult antennae from each gender were dissected. For qRT-PCR analysis, we collected 50 male antennae (MA), 50 female antennae (FA), 50 heads $(+\circ: \hat{O}=1: 1 ; \mathrm{H})$ whose antennae were cut off and 50 legs $\left(+\frac{P}{0} \hat{O}=1: 1 ; \mathrm{L}\right)$ in three replications from 1 day old virgin adults. After collection, the samples were preserved in liquid nitrogen for further use.

\section{Identification of putative chemosensory receptor proteins}

The antenna transcriptomes of unmated H. rhodope were reported in our previous study. Six female and male antennae samples (three biological replicates each gender) were separately sequenced using the Illumina Hiseq 4000 platform. The female and male antennae yielded at least 21.62 and 21.39 million clean reads per sample, respectively. All clean reads from male and female samples were combined into an assembly that generated 50,218 unigenes with a mean length of 1,031.08 bp and an N50 length of 2,247 bp (Yang et al., 2020). A tBLASTn analysis was performed using available ORs, IRs, GRs and SNMPs protein sequences from lepidopteran species as 'queries' to identify candidate unigenes in H. rhodope. All putative ORs, IRs, GRs and SNMPs were manually checked using the BLASTx program in the National Center for Biotechnology Information (NCBI) with a cut-off E-value of $10^{-5}$. The OR genes were numbered arbitrarily, while the IR, GR and SNMP genes were named based on the highest scoring Blastx match from the NR database. Open reading frames (ORFs) were predicted using the ORF Finder (https://www.ncbi.nlm.nih.gov/orffinder/). The TMDs of the putative chemoreceptor genes were predicted on the TOPCONS website (http://topcons.net/).

\section{Comparison of transcript abundances of chemosensory receptor genes}

Using the assembled transcriptome as reference sequences, the clean data from various samples of $H$. rhodope were mapped back onto the reference sequences using Bowtie2 v2.1.0 software (Langmead et al., 2009). The unigene expression levels among various samples were estimated with RSEM (Li \& Dewey, 2011) according to the read count values of the unigenes for each sample, which were obtained from the mapping results. The transcript abundance of candidate chemoreceptor genes in male and female antennal transcriptomes was calculated using fragments per kb per million fragments (FPKM) values (Li \& Dewey, 2011). Heatmap plots of the chemoreceptor gene expression were generated in Microsoft Excel, using the conditional formatting option. For each plot, blue color was used for the minimum value, yellow for the midpoint and red for the maximum value. For all gene families, the range was specified for each tissue type independently, such that the color gradient was set based upon the highest FPKM values within each tissue, not across all tissues. The criteria for estimating significant differentially expressed genes were set as the absolute value of $\log 2$ Fold Change $>1$.

\section{Phylogenetic analysis}

Peer) reviewing PDF | (2020:05:48878:1:2:NEW 21 Aug 2020) 
202 Phylogenetic trees of candidate chemoreceptors were constructed using MEGA7.0 software

203 (Kumar, Stecher \&Tamura, 2016). Amino acid sequences were first aligned using the program

204 ClustalX (http://www.clustal.org/clustal2/). Maximum likelihood (ML) statistical method was

205 used to infer evolutionary relationship and unrooted trees were built with the Jones-Taylor-

206 Thornton (JTT) model used to obtain the initial trees for the heuristic search. The tree calculation

207 was carried out using 1000 bootstrap replicates. Generated trees were edited using Figtree

208 software (http://tree.bio.ed.ac.uk/software/figtree/). The protein sequences of chemoreceptors

209 used for building phylogenetic trees are listed in Supplementary file 1.

210

211 Expression level analysis

212 We selected 10 ORs, all IRs, 3 GRs and 2 SNMPs to verify their expression profiles. 10 ORs and

2133 GRs were selected for qRT-PCR analysis because they were significant DEGs between male

214 and female antennae according to the criteria as described above. The relative expression levels

215 of these genes in different tissues were determined using qRT-PCR. Different tissues were

216 collected from both male and female adults as described above. Total RNA was extracted using

217 TRIzol reagent. First-strand cDNA was synthesized from $2 \mu \mathrm{g}$ of total RNA using the

218 PrimeScript RT reagent kit with gDNA Eraser (Takara, Dalian, China) according to the

219 manufacturer's instructions. qRT-PCR primers (Supplementary Table S1) were designed with

220 Primer Premier 5 (Premier Biosoft International, CA, USA) and synthesized by Sangon Biotech

221 Co., Ltd (Shanghai, China). The glyceraldehyde-phosphate dehydrogenase (GAPDH) gene was

222 identified from the H. rhodope antennal transcriptome and used as the internal reference (Yang

223 et al., 2020). The qRT-PCR was conducted on a StepOne Plus Real-time PCR System (Applied

224 Biosystems, Foster City, CA, USA) using SYBR Premix ExTaq II (Tli RNaseH Plus) (Takara,

225 Dalian, China). Each reaction ( $20 \mu \mathrm{L}$ volume) contained $2 \mu \mathrm{L}$ cDNA, $10 \mu \mathrm{L}$ SYBR $^{\circledR}$ Premix Ex

226 Taq, $0.4 \mu \mathrm{L}$ forward and reverse primers $(10 \mu \mathrm{M})$, and $7.2 \mu \mathrm{L}$ RNase-free double distilled water.

227 qRT-PCR was performed as follows: initial denaturation at $95^{\circ} \mathrm{C}$ for $3 \mathrm{~min}, 40$ cycles at $95^{\circ} \mathrm{C}$ for

$22810 \mathrm{~s}$ and $60^{\circ} \mathrm{C}$ for $30 \mathrm{~s}$. Melting curve analysis was performed from $55^{\circ} \mathrm{C}$ to $95^{\circ} \mathrm{C}$ to determine

229 the specificity of qPCR primers. To determine the efficiency of the qPCR primers, a standard

230 curve (cDNA concentration vs. $\mathrm{Ct}$ ) was produced with a 5-fold dilution series of legs cDNA

231 corresponding to one microgram total RNA. qRT-PCR efficiencies were then calculated

232 according to the equation: $\mathrm{E}=\left(10^{[-1 / \text { slope }]}-1\right) * 100$ (Pfaffl, 2001; Radonić et al., 2004). The

$2332^{-\Delta \Delta C t}$ method was used to analyze gene expression profiles (Pfaffl, 2001). All data were

234 normalized to endogenous GAPDH rRNA levels from the identical tissue sample, and the

235 relative fold change in the different tissues was calculated with the transcript level of the legs as

236 the calibrator. Each reaction was performed in triplicate (from three biological replicates).

237 Relative expressions of each test gene from the different tissues were compared using a one-

238 way analysis of variance (ANOVA) in SPSS 20.0 software (IBM, Chicago, IL, USA) followed

239 by the least significant difference test (LSD) (critical values corresponding to $P=0.05$ ).

240

241

\section{Results}


242 Identification and phylogenetic analyses of ORs in $\boldsymbol{H}$. rhodope

243 A total of 45 candidate ORs, including 44 conventional ORs and one ORco, were identified in $H$. 244 rhodope antennal transcriptome (Table 1). Among these genes, 25 candidate OR genes had 7

245 TMDs and full ORFs encoding more than 370 amino acids. HrhoORco shared $85.44 \%$ sequence 246 identity with Galleria mellonella ORco (NCBI ID: QEI46859) and $84.81 \%$ sequence identity

247 with Ostrinia furnacalis ORco (NCBI ID: XP_028178675). Gene expression levels of all 45 ORs 248 were assessed using the FPKM values, where 23 ORs were relatively highly expressed in the FA 249 and two ORs were relatively highly expressed in the MA. The remaining 20 ORs showed no 250 differences in expression levels between sexes (Fig. 1A).

251

252

253

254

255

256

257

258

259

260

261

262

263

264

265

266

267

268

269

270

271

272

273

274

275

276

277

278

279

280

281

A phylogenetic tree was constructed with 195 ORs from H. rhodope, B. mori, H. armigera, O. furnacalis, Cnaphalocrocis medinalis, Heliothis virescens, Dendrolimus punctatus, Spodoptera littoralis and M. sexta. Most of the HrhoORs have orthologous relationships with the other lepidopteran species (Fig. 2). As anticipated, HrhoORco clustered in the ORco family. In addition, four HrhoORs (HrhoOR4, 16, 39 and 40) were segregated into one unique clade whereas HrhoOR15/23, HrhoOR2/32 and HrhoOR21/28 clustered together. Interestingly, $H$. rhodope ORs lacked in the classical moth pheromone receptor (PR) clade, while HrhhoOR14 and HrhoOR30 clustered within a novel PR clade containing SlitOR5 in S. littoralis and several candidate PRs from $D$. punctatus. These ORs were recently identified as a novel lineage of PRs detecting type I pheromones in Lepidoptera (Bastin-Héline et al., 2019; Shen et al., 2020).

\section{Identification and phylogenetic analyses of IRs in $\boldsymbol{H}$. rhodope}

Nine putative IRs were identified from the antennal transcriptome of $H$. rhodope and named as HrhoIR8a, 21a, 76b, 41a, 60a, 75q2, 68a, 75p and 40a based on homologous sequences from other insects (Table 2). All candidate IRs were partial sequences and the TMDs of IRs ranged from 1 to 4.Three IRs (HrhoIR8a, 60a and 75q.2) were significantly higher expressed in FA than in MA. The highest FPKM value of IRs (HrhoIR68a, FPKM =202.80) was found in the FA (Fig. 1B).

A phylogenetic tree was constructed with 99 IRs from H. rhodope, Cydia pomonella, Epiphyas postvittana and D. melanogaster (Fig. 3). We found that HhroIR8a, HrhoIR76b, HrhoIR75p, HrhoIR75q.2, HrhoIR21a, HrhoIR68a, HrhoIR40a, HhroIR60 and HrhoIR41a were clustered into IR8a, IR76b, IR75, IR21a, IR68a, IR40a, IR60a and IR41a clades with high bootstrap values, respectively. According to their positions in the phylogenetic tree and based on the strong bootstrap support, the candidate HrhoIRs names were consistent with the number and suffix of known IRs. However, no orthologs for IR25a, IR75d, IR93a and IR87a were identified from $H$. rhodope.

\section{Identification and phylogenetic analyses of GRs in $\boldsymbol{H}$. rhodope}

We identified eight candidate GR genes in the antennal transcriptomes of H. rhodope (Table 3). All GR genes had incomplete ORFs ranging from 390 to 1218 bp in length with 1-5 TMDs. The FPKM values of all HrhoGRs were less than those of OR, IR and SNMP genes. Three GR genes 
282

283

284

285

286

287

288

289

290

291

292

293

294

295

296

297

298

299

300

301

302

303

304

305

306

307

308

309

310

311

312

313

314

315

316

317

318

319

320

321

(HrhoGR3, HrhoIR29 and HrhoIR64a) were significantly higher expressed in the FA than in the MA (Fig. 1C).

Phylogenetic analysis of 81 GRs from five lepidopteran species showed that several candidate GRs were closely related to other known insect GRs that function as sugar receptors, bitter receptors and $\mathrm{CO}_{2}$ receptors. HrhoGR7 and HhroGR64a clustered into sugar receptor clade, HrhoGR67 clustered into bitter receptor subfamily and HrhoGR2 clustered into the $\mathrm{CO}_{2}$ receptor clade. Notably, the other four GRs (HrhoGR3/4/29/68.1) had orthologous relationships with $C$. pomonella (Fig. 4).

\section{Identification and phylogenetic analyses of SNMPs in $\boldsymbol{H}$. rhodope}

We identified two candidate SNMPs (HrhoSNMP1 and HrhoSNMP2) from antennal transcriptomes of H. rhodope (Table 4). Two SNMP genes had intact ORFs (length: 1422-1581 bp) with 1-2 TMDs. According to the FPKM values of SNMPs, HrhoSNMP1 and HrhoSNMP2 were equally expressed in both the FA and the MA groups (Fig. 1D). SNMPs phylogenetic tree revealed that HrhoSNMP1 and HrhoSNMP2 clustered into SNMP1 and SNMP2 clades, respectively (Fig. 5).

\section{Tissue-specific expression analysis by qRT-PCR}

To assess the difference in expression of chemoreceptor genes between male and female antennae, heads (without antennae) and legs and test the RNA-Seq results, 10 ORs, all IRs, 3 GRs and 2 SNMPs were selected for qRT-PCR. The results showed that the expression levels of the tested genes in the male and female antennae were consistent with the RNA-Seq results. The qRT-PCR results revealed that all $10 \mathrm{HrhoORs}$ were significantly higher expressed in the antennae than in the heads and legs. Furthermore, 6 OR genes (HrhoOR9, 24, 26, 33, 37 and 40) were significantly higher expressed in the FA while HrhoOR4 and HrhoOR 13 were significantly higher expressed in the MA. Interestingly, HrhoORco and HrhoOR11 showed no differences in expression between sexes (Fig. 6A-J). Notably, HrhoORco, HrhoOR4 and HrhoOR37 showed higher expression levels in the antennae compared with the expression levels of other HrhoORs.

The qRT-PCR results revealed that the expression of 5 IRs (HrhoIR8a, 21a, 40a, 60a and 76b) was significantly higher in the FA while that of 3 genes (HrhoIR41a, 68a and 75p) was equally expressed in the antennae of both sexes. Additionally, we found that HrhoIR75q.2 and HrhoIR40 had higher expression in the heads compared with other genes (Fig. 6K-S).

HrhoGR2 and HrhoGR64a displayed significant FA-specific expressions, while HrhoGR67 had significantly higher expression in the heads than in other tissues (Fig. 6T-V). HrhoSNMPI and $H r h o S N M P 2$ were significantly expressed at high levels in the antennae in both sexes; HrhoSNMP2 was also highly expressed in heads (Fig. 6W-X).

\section{Discussion}

To date, a growing number of chemosensory genes have been identified in moths. However, most of the genes are from nocturnal moths (Ditrysia) (Yuvaraj et al., 2018). Currently, the 
322

323

324

325

326

327

328

329

330

331

332

333

334

335

336

337

338

339

340

341

342

343

344

345

346

347

348

349

350

351

352

353

354

355

356

357

358

359

360

361

molecular basis of chemoreception in the Zygaenidae family of diurnal moths is poorly understood. The identification and characterization of the chemoreceptor genes of $H$. rhodope, an important forest pest and diurnal moth, will improve our understanding of olfaction mechanisms in Zygaenidae and provide the basis for further exploration of sensory disparities between the diurnal and nocturnal moths.

In the present study, we identified 45 ORs, 9 IRs, 8 GRs and 2 SNMPs from our previous $H$. rhodope transcriptomic data (Yang et al., 2020). The number of chemoreceptor genes in $H$. rhodope was less compared to previously reported numbers in other nocturnal lepidopteran species, such as 62 ORs, 20 IRs and 16 GRs in Mythimna separata (Du et al., 2018), 64 ORs, 22 IRs and 30 GRs in Spodoptera exigua (Zhang et al., 2018), 60 ORs, 21 IRs and 197 GRs in $H$. armigera (Liu et al., 2014; Xu et al., 2016), 60 ORs, 17 IRs and 17 GRs in S. littoralis (Walker III et al., 2019) and 58 ORs, 21 IRs and 22 GRs in C. pomonella (Walker III et al., 2016). Previous studies reported that different chemosensory behavior (Zhang et al., 2017), life stage (He et al., 2017), ecological niche breadth (Gouin et al., 2017), phenotype (Purandare \& Brisson, 2020), mating status (Jin et al., 2017), circadian rhythm (Gadenne, Barrozo \& Anton, 2016) and feeding trait (Taparia, Ignell \& Hill, 2017) influence the variation in chemosensory gene number. The smaller number of genes identified in the current study may be due to the following reasons. Firstly, we identified olfactory related genes from antenna transcriptome data only, whereas previous studies used transcriptome data from different developmental stages and organs, especially for GRs. Secondly, the number of chemosensory genes may be related to its ability for diverse host-odor detection to feed on the range size of host plants (Gouin et al., 2017). $H$. rhodope is an oligophagous pest requiring no additional olfactory proteins to perceive single host chemicals (Gouin et al., 2017; Yang et al., 2020). Finally, H. rhodope is a diurnal insect, although it is a moth and not a butterfly. Diurnal moths mainly depend on visual cues while nocturnal moths mainly depend on their odorant signals (Vogt, Grosse-Wilde \& Zhou, 2015). Chemosensory gene loss in diurnal moths compared to nocturnal moths could result from the shift from olfactory to visual communication.

Odorant receptors act as signal-transducers that convert chemical molecules to electrical signals in insects (Leal, 2013). ORs are desirable targets for alternative strategies to control insect populations due to their critical roles in the initial steps of the olfactory response process (Venthur \& Zhou, 2018). In this study, 44 specific ORs and 1 ORco were identified. ORco genes are widely expressed and highly conserved among lepidopteran species and play a key role in insect olfaction (Touhara \& Vosshall, 2009). HrhoORco shared a high degree of similarity with the ORco genes of other insects and clustered into the ORco subfamily. Previous studies showed that many ORco mutants were anosmic. For instance, mutagenesis of BmolORco and MsexORco severely disrupted the olfactory system (Liu et al., 2017a; Fandino et al., 2019), suggesting that the ORco genes might be the primary potential target genes for pest management.

Generally, phylogenetic analysis of lepidopteran ORs showed two specific branches comprising the ORco orthologs and the traditional PR clade. Interestingly, no PRs were related to the conserved lepidopteran PR clade. However, two ORs (HrhoOR14 and 30) clustered into a 
362

363

364

365

366

367

368

369

370

371

372

373

374

375

376

377

378

379

380

381

382

383

384

385

386

387

388

389

390

391

392

393

394

395

396

397

398

399

400

401

novel lineage distantly related to the conserved lepidopteran PR clade. Notably, several DpunPRs (Shen et al., 2020) and SlitOR5 (Bastin-Héline et al., 2019) that grouped with HrhoOR14 and 30 were recently characterized as a new evolution origin of PRs in Lepidoptera. We speculate that these two ORs may be involved in the detection of $H$. rhodope sex pheromones, although further functional analysis is needed to confirm this hypothesis. Besides phylogenetic analysis, the expression pattern is another main criterion used to select candidate PRs for functional studies. SlitOR5 and DpunPRs were all highly or specifically expressed in the MA. Unfortunately, we did not conduct the expression levels of HrhoOR14 and 30 by qRT-PCR. However, according to the FPKM values, HrhoOR14 exhibited male-biased expression while HrhoOR30 exhibited female-biased expression. This expression pattern was similar to the novel lineage of PRs, whereby approximately one-half of the ORs were male-biased and the other half were female-biased.

The expression patterns of candidate genes may reveal important clues into their functions. Overall, sexually differential expressions of ORs in antennae suggest a possible involvement of PRs in sexual behaviors. Female-biased ORs are believed to play a role in detecting ovipositionrelated odorant (Pelletier et al., 2010) or pheromones (signals) released by males (Anderson et al., 2009), whereas male-biased ORs potentially function in the detection of sex pheromones released by females (Zhang \& Löfstedt, 2013). ORs expressed evenly between female and male antennae are predicted to take part in general odorant perception (Yan et al., 2015). Therefore, we speculate that male-biased expressed ORs (HrhoOR4 and 13) are likely to participate in female pheromone perception. On the other hand, female-biased expressed HrhoORs, including HrhoOR9, 24, 26, 33, 37 and 40, may function in the detection of oviposition-related plant odors or male-produced courtship pheromones. The other HrhoORco and HrhoOR11 with approximately equal expression levels between female and male antennae are likely to function in the detection of food source odors. In addition, HrhoOR37 was orthologous to CmedOR32 according to phylogenetic analysis, and the expression levels of these two OR genes were higher in the FA than in the MA (Liu et al., 2017b). Therefore, we speculate that these two orthologous OR genes may play similar roles in odor detection. Detailed functional studies of these sexspecific ORs should be performed in further studies.

IRs are a new subfamily of chemosensory receptors. IRs are relatively conserved in both the sequence and the expression patterns and are widely distributed throughout the body parts, including the labellum, pharynx, leg and wing compared with ORs (Koh et al., 2014; Rimal \& Lee 2018). In this study, 9 IRs were identified. IR8a, IR25a and IR76b were regarded as coreceptors just like ORco as they were co-expressed along with other stimulus-specific IRs (Abuin et al., 2011). HrhoIR8a and HrhoIR76b clustered in the IR8a/IR25a/IR76b subfamily, indicating that these two genes may perform a function similar to that of the co-receptors in $D$. melanogaster. Interestingly, IR25a, one of the conserved IR co-receptors, was not identified in this study. The failure to identify IR25a could be due to the low expression levels in the antennae in this species. Other IRs found in antennae belong to the conserved "antennal IRs" (Croset et al., 2010) and have their respective orthologs. This revealed that IRs are highly conserved across 
402 insect orders and HrhoIRs may have conserved functions, retaining their roles as IRs in other 403 Lepidoptera species. However, the function of these IRs has been studied in D. melanogaster. 404 For example, DmelIR21a and 25a are essential for cool sensing (Ni et al., 2016), IR40 and IR68a 405 are involved in the detection of temperature and humidity (Enjin et al., 2016; Frank et al., 2017), 406 IR75 functions in acid sensing (Prieto-Godino et al., 2017) and IR76b is involved in the 407 sensation of taste (Ganguly et al., 2017). Therefore, HrhoIR21a, HrhoIR40a, HrhoIR68a, HrhoIR75 and HrhoIR76b are predicted to perform functions similar to those in D. melanogaster, which may involve activation by acids, temperatures, humidity and other factors. The function of IRs in lepidopteran species is still unclear, warranting further functional studies. In the expression patterns of the 9 IRs identified, 8 HrhoIRs were highly expressed in the antennae, indicating that these IRs may participate in odor, thermo- and hygrosensation. Three IRs, HrhoIR40a, HrhoIR75p and HrhoIR75q.2, were also expressed in the heads and legs except for the antennae. Notably, HrhoIR75q.2 had the highest expression level in the heads compared with the other four tissues studied. The expression of these three IRs in different tissues suggests that they may have multiple functions. In addition to olfaction, IRs are associated with gustation, hygrosensation and thermosensation (Rimal \& Lee, 2018). In D. melanogaster, IR21a, IR40a, $I R 68 a$ and $I R 93 a$ were expressed in the antennae and played critical roles in thermosensation and hygrosensation (Enjin et al., 2016; Knecht et al., 2016; Ni et al., 2016; Frank et al., 2017; Rimal \& Lee, 2018). In our study, HrhoIR21a and HrhoIR40a showed a close evolutionary relationship to DmelIR21a and DmelIR40a. Additionally, HrhoIR2 Ia and HrhoIR40a showed high expression levels in the antennae (Fig. 6L-M). However, further analysis should be carried out to establish whether these two IRs function in the mediation of thermotransduction in H. rhodope.

GRs function in detecting $\mathrm{CO}_{2}$ and nonvolatile bitter, sugar, amino acid and plant secondary metabolite compounds via contact chemosensation (Agnihotri, Roy \& Joshi, 2016). Phylogenetic tree analysis showed that HhroGR2 clustered with BmorGR2 in the $\mathrm{CO}_{2}$ receptor subfamily (Fig. 4). Moreover, just like BmorGR2, HrhoGR2 exhibits higher expression levels in the antennae compared with other tissues (Guo et al., 2017). Therefore, HrhoGR2 may contribute to $\mathrm{CO}_{2}$ detection. Furthermore, HrhoGR67 was clustered into a bitter receptor family and highly expressed in the heads (Fig. 4 and 6V). Kasubuchi et al. (2018) reported three bitter receptors (BmorGR16/18/53) expressed at different levels in the labrum, maxillary palp and maxillary galea, which perceived various feeding deterrents such as coumarin and caffeine. Further studies should explore whether HrhoGR67 has a similar function to the three receptors.

Generally, there are two SNMPs in insects, which were also identified in the present study. HrhoSNMP1 and HrhoSNMP2 were highly expressed in H. rhodope antennae, suggesting that they might be involved in olfactory functions. However, HrhoSNMP2 was also expressed in the heads. Similar broad expression patterns were also observed in other moth species, such as Sesamia inferens, C. medinalis, Spodoptera litura and H. armigera (Zhang et al., 2013; Zhang et al., 2015; Zhang et al., 2020). The ubiquitous expression pattern of SNMP2 means that in addition to odorant detection, they may have various functions specific to different organs (Vogt et al., 2009). On the other hand, SNMP1 subfamilies are implicated in mediating responses to 
442 lipid pheromones ( $\mathrm{Li}$ et al., 2014). HrhoSNMP1 showed higher expression levels in the FA,

443 indicating that HrhoSNMP1 may be associated with the detection of sex pheromones. However,

444 SNMP1 identified from $M$. destructor was reported not to be crucial in pheromone perception

445 (Andersson et al., 2016). This finding calls for further investigation to determine whether

446 HrhoSNMP1 functions in pheromone detection in H. rhodope.

447

448

449

\section{Conclusion}

450

451

452

453

454

455

456

457

458

459

460

461

462

463

464

465

466

467

468

469

470

471

472

473

474

475

476

477

478

479

480

481

482

483

484

485

486

487

In conclusion, 45 ORs, 9 IRs, 8 GRs and 2 SNMPs were identified in antennae transcriptomes of $H$. rhodope. The putative functions of some genes were predicted by comparative phylogenetic analyses and tissue expression assays. Our results enrich the olfactory gene inventory of $H$. rhodope and provide the foundation for further research on the molecular mechanism and evolution of the olfactory system in diurnal moths.

\section{Acknowledgements}

We thank students Deng-Gao Ji, Jian-Wei Ding and An-Ran Tan (Henan University of Science and Technology) for their help in collecting insects. We also thank Joseph Gillespie, Arthur de Fouchier, Nicolas Montagné and the other anonymous referee for their helpful comments that improved the manuscript.

\section{References}

Abuin L, Bargeton B, Ulbrich MH, Isacoff EY, Kellenberger S, Benton R. 2011. Functional architecture of olfactory ionotropic glutamate receptors. Neuron 69:44-60 DOI: 10.1016/j.neuron.2010.11.042.

Agnihotri AR, Roy AA, Joshi RS. 2016. Gustatory receptors in Lepidoptera: chemosensation and beyond. Insect Molecular Biology 25:519-529 DOI: 10.1111/imb.12246.

Anderson AR, Wanner KW, Trowell SC, Warr CG, Jaquin-Joly E, Zagatti P, Robertson H, Newcom RD. 2009. Molecular basis of female-specific odorant responses in Bombyx mori. Insect Biochemistry and Molecular Biology 39:189-197 DOI: 10.1016/j.ibmb.2008.11.002.

Andersson MN, Corcoran JA, Zhang DD, Hillbur Y, Newcomb RD, Löfstedt C. 2016. A sex pheromone receptor in the hessian fly Mayetiola destructor (Diptera, Cecidomyiidae). Frontiers in Cellular Neuroscience 10:212 DOI: 10.3389/fncel.2016.00212.

Andersson MN, Löfstedt C, Newcomb RD. 2015. Insect olfaction and the evolution of receptor tuning. Frontiers in Ecology and Evolution 3:53 DOI: 10.3389/fevo.2015.00053

Arikawa K. 2017. The eyes and vision of butterflies. Journal of Physiology-London 595:5457-5464 DOI: 10.1113/JP273917.

Bastin-Héline L, de Fouchier A, Cao S, Koutroumpa F, Caballero-Vidal G, Robakiewicz S, Monsempes C, Francois MC, Ribeyre T, Maria A, Chertemps T, de Cian A, Walker III WB, Wang GR, Jacquin-Joly E, Montagné N. 2019. A novel lineage of candidate pheromone receptors for sex communication in moths. eLife 8:e49826. DOI: 10.7554/eLife.49826.

Benton R, Vannice KS, Gomez-Diaz C, Vosshall LB. 2009. Variant ionotropic glutamate receptors as chemosensory receptors in Drosophila. Cell 136:149-162 DOI: 10.1016/j.cell.2008.12.001.

Benton R, Vannice KS, Vosshall LB, 2007. An essential role for a CD36-related receptor in pheromone detection in Drosophila. Nature 450:289-293 DOI: 10.1038/nature06328.

Briscoe AD, Macias-Muñoz A, Kozak KM, Walters JR, Yuan F, Jamie GA, Martin SH, Dasmahapatra KK, Ferguson LC, Mallet J, Jacquin-Joly E, Jiggins CD. 2013. Female behaviour drives expression and evolution of gustatory receptors in butterflies. PLoS Genetics 9:e1003620 DOI: 10.1371/journal.pgen.1003620. 
488

489

490

491

492

493

494

495

496

497

498

499

500

501

502

503

504

505

506

507

508

509

510

511

512

513

514

515

516

517

518

519

520

521

522

523

524

525

526

527

528

529

530

531

532

533

534

535

536

537

538

539

540

Butterwick JA, del Mármol J, Kim KH, Kahison MA, Rogow JA, Walz T, Ruta V. 2018. Cryo-EM structure of the insect olfactory receptor Orco. Nature 560:447-452 DOI: 10.1038/s41586-018-0420-8.

Chen CH, Buhl E, Xu M, Croset V, Rees JS, Lilley KS, Benton R, Hodge JJL, Stanewsky R. 2015. Drosophila ionotropic receptor 25a mediates circadian clock resetting by temperature. Nature 527:516-520 DOI: 10.1038 /nature16148.

Chen L, Wang XY, Lu W, Zheng XL. 2020. Sexual communication in diurnal moths: behaviors and mechanisms. International Journal of Tropical Insect Science Published: 01 June DOI: 10.1007/s42690020-00174-z.

Clyne PJ, Warr CG, Carlson JR. 2000. Candidate taste receptors in Drosophila. Science 287:1830-1834 DOI: 10.1126/science.287.5459.1830.

Clyne PJ, Warr CG, Freeman MR, Lessing D, Kim J, Carlson JR. 1999. A novel family of divergent seventransmembrane proteins: candidate odorant receptors in Drosophila. Neuron 22:327-338 DOI: 10.1016/S0896-6273(00)81093-4.

Costanzo K, Monteiro A. 2007. The use of chemical and visual cues in female choice in the butterfly Bicyclus anynana. Proceedings of the Royal Society B-Biological Science B 274:845e851 DOI: 10.1098/rspb.2006.3729.

Croset V, Rytz R, Cummins SF, Budd A, Brawand D, Kaessmann H, Gibson TJ, Benton R. 2010. Ancient protostome origin of chemosensory ionotropic glutamate receptors and the evolution of insect taste and olfaction. PLoS Genetocs 6:e1001064 DOI: 10.1371/journal.pgen.1001064.

Du LX, Zhao XC, Liang XZ, Gao XW, Liu Y, Wang GR. 2018. Identification of candidate chemosensory genes in Mythimna separata by transcriptomic analysis. BMC Genomics 19:518 DOI: 10.1186/s12864018-4898-0.

Dunipace L, Meister S, McNealy C, Amrein H. 2001. Spatially restricted expression of candidate taste receptors in the Drosophila gustatory system. Current Biology 11:822-835 DOI: 10.1016/s09609822(01)00258-5.

Enjin A, Zaharieva EE, Frank DD, Mansourian S, Suh GSB, Gallio M, Stensmyr MC. 2016. Humidity sensing in Drosophila. Current Biology 26:1352-1358 DOI: 10.1016/j.cub.2016.03.049.

Fandino RA, Haverkamp A, Bisch-Knaden S, Zhang J, Bucks S, Nguyen TAT, Schröder K, Werckenthin A, Rybak J, Stengl M, Knaden M, Hansson BS, Große-Wilde E. 2019. Mutagenesis of odorant coreceptor Orco fully disrupts foraging but not oviposition behaviors in the hawkmoth Manduca sexta. Proceedings of the National Academy of Sciences of the United States of America 116:15677-15685 DOI: 10.1073/pnas.1902089116.

Forstner M, Gohl T, Gondesen I, Raming K, Breer H, Krieger J. 2008. Differential expression of SNMP-1 and SNMP-2 proteins in pheromone-sensitive hairs of moths. Chemical Senses 33:291-299 DOI: 10.1093/chemse/bjm087.

Frank DD, Enjin A, Jouandet GC, Zaharieva EE, Para A, Stenamyr MC, Gallio M. 2017. Early integration of temperature and humidity stimuli in the Drosophila brain. Current Biology 27:2381-2388.e4 DOI: 10.1016/j.cub.2017.06.077.

Gadenne CR, Barrozo B, Anton S. 2016. Plasticity in insect olfaction to smell or not to smell? Annual Review of Entomology 61:317-333 DOI: 10.1146/annurev-ento-010715-023523.

Ganguly A, Pang L, Duong VK, Lee A, Schoniger H, Varady E. Dahanukar A. 2017. A molecular and cellular context-dependent role for Ir76b in detection of amino acid taste. Cell Reports 18:737-750 DOI: 10.1016/j.celrep.2016.12.071.

Gouin A, Bretaudeau A, Nam K, Gimenez S, Aury JM, Duvic B, Hilliou F, Durand N, Montagne N, Darboux I, Kuwar S, Chertemps T, Siaussat D, Bretscheider A, Mone Y, Ahn SJ, Hanniger S, Gosselin Grenet AS, Neunemann D, Maumus F, Luyten I, Labadie K, Xu W, Koutroumpa F, Escoubas JM, Llopis A, Maibeche-Coisne M, Salasc F, Tomar A, Anderson AR, Khan SA, Dumas P, Orsucci M, Guy J, Belser C, Alberti A, Noel B, Couloux A, Mercier J, Nidelet S, Dubois E, Liu NY, Boulogne I, Mirabeau O, Goff GL, Gordon K, Oakeshott J, Consoli FL, Volkoff AN, Fescemyer HW, Marden JH, Luthe DS, Herrero S, Heckel DG, Wincker P, Kergoat GJ, Amselem J, Quesneville H, Groot AT, Jacquin-Joly E, Negre N, Lemaitre C, Legeai F, Alencon E, Fournier P. 2017. Two genomes of highly polyphagous lepidopteran pests (Spodoptera frugiperda Noctuidae) with different host-plant ranges. Scientific Reports 7:11816 DOI: 10.1038/s41598-017-10461-4.

Peer) reviewing PDF | (2020:05:48878:1:2:NEW 21 Aug 2020) 
541

542

543

544

545

546

547

548

549

550

551

552

553

554

555

556

557

558

559

560

561

562

563

564

565

566

567

568

569

570

571

572

573

574

575

576

577

578

579

580

581

582

583

584

585

586

587

588

589

590

591

592

593

Guo H, Cheng T, Chen Z, Jiang L, Guo Y, Liu J, Li S, Taniai K, Asaoka K, Kadono-Okuda K, Arunkumar KP, Wu J, Kishino H, Zhang H, Seth RK, Gopinathan KP, Montagné N, Jacquin-Joly E, Goldsmith MR, Xia Q, Mita K. 2017. Expression map of a complete set of gustatory receptor genes in chemosensory organs of Bombyx mori. Insect Biochemistry and Molecular Biology 82:74-82 DOI: 10.1016/j.ibmb.2017.02.001

Hallem EA, Carlson JR. 2006. Coding of odors by a receptor repertoire. Cell 125:143-160 DOI: 10.1016/j.cell.2006.01.050.

Haverkamp AB, Hansson S, Knaden M. 2018. Combinatorial codes and labeled lines: how insects use olfactory cues to find and judge food mates and oviposition sites in complex environments. Frontiers in Physiology 9:49 DOI: 10.3389/fphys.2018.00049.

He YQ, Feng B, Guo QS, Du YJ. 2017. Age influences the olfactory profiles of the migratory oriental armyworm mythimna separate at the molecular level. BMC Genomics 18:32 DOI: 10.1186/s12864-0163427-2.

Huang BK. 1980. A study on the bionomic characteristics and control of the Bischofia burnet Histia rhodope Cramer. Jouranl of Fujian Agricultural College 1:61-79.

Hussain A, Zhang M, Üçpunar HK, Svensson T, Quillery E, Gompel N, Ignell R, Grunwald Kadow IC. 2016. Ionotropic chemosensory receptors mediate the taste and smell of polyamines. PLoS Biology 14:e1002454 DOI: 10.1371/journal.pbio.1002454.

Jin S, Zhou X, Gu F, Zhong G, Yi X. 2017. Olfactory plasticity: variation in the expression of chemosensory receptors in Bactrocera dorsalis in different physiological states. Frontiers in Physiology 8:672 DOI: 10.3389/fphys.2017.00672.

Jin X, Ha TS, Smith DP. 2008. SNMP is a signaling component required for pheromone sensitivity in Drosophila. Proceedings of the National Academy of Sciences of the United States of America 105:1099611001 DOI: 10.1073/pnas.0803309105.

Kasubuchi M, Shii F, Tsuneto K, Yamagishi T, Adegawa S, Endo H, Sato R. 2018. Insect taste receptors relevant to host identification by recognition of secondary metabolite patterns of non-host plants. Biochemical and Biophysical Research Communications 499:901-906 DOI: 10.1016/j.bbrc.2018.04.014.

Knecht ZA, Silbering AF, Ni L, Klein M, Budelli G, Bell R, Abuin L, Ferrer AJ, Samuel ADT, Benton R, Garrity PA. 2016. Distinct combinations of variant ionotropic glutamate receptors mediate thermosensation and hygrosensation in Drosophila. eLife 5:e17879 DOI: 10.7554/eLife.17879.

Koh TW, He Z, Gorur-Shandilya S, Menuz K, Larter NK, Stewart S, Carlson JR. 2014. The Drosophila IR20a clade of ionotropic receptors are candidate taste and pheromone receptors. Neuron 83:850-865 DOI: 10.1016/j.neuron.2014.07.012.

Kumar S, Stecher G, Tamura K. 2016. MEGA7: molecular evolutionary genetics analysis version 7.0 for bigger datasets. Molecular Biology and Evolution 33:1870-1874 DOI: 10.1093/molbev/msw054.

Langmead B, Trapnell C, Pop M, Salzberg SL. 2009. Ultrafast and memory-efficient alignment of short DNA sequences to the human genome. Genome Biology 10:R25 DOI: 10.1186/gb-2009-10-3-r25.

Leal WS. 2013. Odorant reception in insects: roles of receptors binding proteins and degrading enzymes. Annual Review Entomology 58:373-391 DOI: 10.1146/annurev-ento-120811-153635.

Li B, Dewey CN. 2011. RSEM: accurate transcript quantification from RNA-Seq data with or without a reference genome. BMC Bioinformatics 12:323 DOI: 10.1186/1471-2105-12-323.

Li ZZ, Ni JD, Huang J, Montell C. 2014. Requirement for Drosophila SNMP1 for rapid activation and termination of pheromone-induced activity. PLoS Genetics 10:e1004600 DOI: 10.1371/journal.pgen.1004600.

Liu NY, Xu W, Papanicolaou A, Dong SL, Anderson A. 2014. Identification and characterization of three chemosensory receptor families in the cotton bollworm Helicoverpa armigera. BMC Genomics 15:597 DOI: 10.1186/1471-2164-15-597.

Liu Q, Liu W, Zeng BS, Wang GR, Hao DJ, Huang YP. 2017a. Deletion of the Bombyx mori odorant receptor co-receptor (BmOrco) impairs olfactory sensitivity in silkworms. Insect Biochemistry and Molecular Biology 86:58-67 DOI: 10.1016/j.ibmb.2017.05.007.

Liu S, Wang WL, Zhang YX, Zhang BX, Rao XJ, Liu XM, Wang DM, Li SG. 2017b. Transcriptome sequencing reveals abundant olfactory genes in the antennae of the rice leaffolder Cnaphalocrocis medinalis (Lepidoptera:Pyralidae). Entomological Science 20:177-188 DOI: 10.1111/ens.12253.

Martin JP, Beyerlein A, Dacks AM, Reisenman CE, Riffell JA, Lei H, Hildebrand JG. 2011. The neurobiology

Peer] reviewing PDF | (2020:05:48878:1:2:NEW 21 Aug 2020) 
594

595

596

597

598

599

600

601

602

603

604

605

606

607

608

609

610

611

612

613

614

615

616

617

618

619

620

621

622

623

624

625

626

627

628

629

630

631

632

633

634

635

636

637

638

639

640

641

642

643

644

645

646

of insect olfaction: Sensory processing in a comparative context. Progress in Neurobiology 95:427-447

DOI: 10.1016/j.pneurobio.2011.09.007.

Monteys VSI, Quero C, Santa-Cruz MC, Rosell G, Guerrero A. 2016. Sexual communication in day-flying Lepidoptera with special reference to castniids or 'butterfly-moths'. Bulletin of Entomological Research 106:421-431 DOI: 10.1017/S0007485316000158.

Ni L, Klein M, Svec KV, Budelli G, Chang EC, Ferrer AJ, Benton R, Damuel AD, Garrity PA. 2016. The ionotropic receptors IR21a and IR25a mediate cool sensing in Drosophila. eLife 5:e13254 DOI: 10.7554/eLife. 13254.

Ning C, Yang K, Xu M, Huang LQ, Wang CZ. 2016. Functional validation of the carbon dioxide receptor in labial palps of Helicoverpa armigera moths. Insect Biochemistry and Molecular Biology 73:12-19 DOI: 10.1016/j.ibmb.2016.04.002.

Pelletier J, Hughes DT, Luetje CW, Leal WS. 2010. An odorant receptor from the southern house mosquito Culex pipiens quinquefasciatus sensitive to oviposition attractants. PLoS ONE 5:e10090 DOI: 10.1371/journal.pone.0010090.

Pfaffl MW. 2001. A new mathematical model for relative quantification in real-time RT-PCR. Nucleic Acids Research 29:e45 DOI: 10.1093/nar/29.9.e45.

Pregitzer P, Greschista M, Breer H, Krieger J. 2014. The sensory neurone membrane protein SNMP1 contributes to the sensitivity of a pheromone detection system. Insect Molecular Biology 23:733-742 DOI: 10.1111/imb.1211.

Preiss R, Kramer E. 1986. Mechanism of pheromone orientation in flying moths. Naturwissenschaften 73:555e557.

Prieto-Godino LL, Rytz R, Cruchet S, Bargeton B, Abuin L, Silbering AF. Ruta V, Peraro MD, Benton R. 2017. Evolution of acid-sensing olfactory circuits in Drosophilids. Neuron 93:661-676.e6 DOI: 10.1016/j.neuron.2016.12.024

Purandare SR, Brisson JA. 2020. Divergent chemosensory gene expression accompanies ecological specialisation of pea aphid morphs. Ecological Entomology 45:364-368 DOI: 10.1111/een.12803.

Radonić A, Thulke S, Mackay IM, Landt O, Siegert W, Nitsche A. 2004. Guideline to reference gene selection for quantitative real-time PCR. Biochemical and Biophysical Research Communications 313:856-62 DOI: 10.1016/j.bbrc.2003.11.177.

Rimal S, Lee Y. 2018. The multidimensional ionotropic receptors of Drosophila melanogaster. Insect Molecular Biology 27:1-7 DOI: 10.1111/imb.12347.

Robertson HM. 2019. Molecular evolution of the major arthropod chemoreceptor gene families. Annual Review Entomology 64:227-242 DOI: 10.1146/annurev-ento-020117-043322.

Rogers ME, Krieger J, Vogt RG. 2001. Antennal SNMPs (sensory neuron membrane proteins) of lepidoptera define a unique family of invertebrate CD36-like proteins. Journal of Neurobiology 49:47-61 DOI: 10.1002/neu.1065.

Sato K, Pellegrino M, Nakagawa T, Vosshall LB, Touhara K. 2008. Insect olfactory receptors are heteromeric ligand-gated ion channels. Nature 452:1002-1006 DOI: 10.1038/nature06850.

Scott K, Brady RJr, Cravchik A, Morozov P, Rzhetsky A, Zuker C, Axel R. 2001. A chemosensory gene family encoding candidate gustatory and olfactory receptors in Drosophila. Cell 104:661-673. DOI: 10.1016/s0092-8674(01)00263-x.

Senthilan PR, Piepenbrock D, Ovezmyradov G, Nadrowski B, Bechstedt S, Pauls S, Winkler M, Möbius W, Howard J, Göpfert MC. 2012. Drosophila auditory organ genes and genetic hearing defects. Cell 150:1042-1054 DOI: 10.1016/j.cell.2012.06.043.

Shen SF, Cao S, Zhang Z, Kong XB, Liu F, Wang GR, Zhang SF. 2020. Evolution of sex pheromone receptors in Dendrolimus punctatus Walker (lepidoptera: Lasiocampidae) is divergent from other moth species. Insect biochemistry and molecular biology 122:10335 DOI:10.1016/j.ibmb.2020.103375.

Subchev M. 2014. Sex pheromone communication in the family Zygaenidae (Insecta: Lepidoptera): A review. Acta Zoologica Bulgarica 66:147-157.

Sun L, Wang Q, Zhang YX, Yan YT, Guo HW, Xiao Q, Zhang YJ. 2019. Expression patterns and colocalization of two sensory neurone membrane proteins in Ectropis obliqua Prout a geometrid moth pest that uses Type-II sex pheromones. Insect Molecular Biology 28:342-354 DOI: 10.1111/imb.12555.

Taparia T, Ignell R, Hill SR. 2017. Blood meal induced regulation of the chemosensory gene repertoire in the

Peer) reviewing PDF | (2020:05:48878:1:2:NEW 21 Aug 2020) 
647

648

649

650

651

652

653

654

655

656

657

658

659

660

661

662

663

664

665

666

667

668

669

670

671

672

673

674

675

676

677

678

679

680

681

682

683

684

685

686

687

688

689

690

691

692

693

694

695

696

697

698

699 southern house mosquito. BMC Genomics 18:393 DOI: 10.1186/s12864-017-3779-2.

Touhara K, Vosshall LB. 2009. Sensing odorants and pheromones with chemosensory receptors. Annual Review Physiology 71:307-332 DOI: 10.1146/annurev.physiol.010908.163209.

Venthur H, Zhou JJ. 2018. Odorant receptors and odorant-binding proteins as insect pest control targets: a comparative analysis. Frontiers in Physiology 9:1163 DOI: 10.3389/fphys.2018.01163.

Vogt RG, Grosse-Wilde E, Zhou JJ. 2015. The lepidoptera odorant binding protein gene family:gene gain and loss within the GOBP/PBP complex of moths and butterflies. Insect Biochemistry and Molecular Biology 62:142-153 DOI: 10.1016/j.ibmb.2015.03.003.

Vogt RG, Miller NE, Litvack R, Fandino RA, Sparks J, Staples J, Friedman R, Dickens JC. 2009. The insect SNMP gene family. Insect Biochemistry and Molecular Biology 39:448-456 DOI: 10.1016/j.ibmb.2009.03.007.

Walker III WB, Gonzalez F, Garczynski SF, Witzgall P. 2016. The chemosensory receptors of codling moth Cydia pomonella-expression in larvae and adults. Scientific Reports 6:23518 DOI: 10.1038/srep23518.

Walker III WB, Roy A, Anderson P, Schlyter F, Hansson BS, Larsson MC. 2019. Transcriptome analysis of gene families involved in chemosensory function in Spodoptera littoralis (Lepidoptera: Noctuidae). BMC Genomics 20:428 DOI: 10.1186/s12864-019-5815-x.

Wanner KW, Robertson HM. 2008. The gustatory receptor family in the silkworm moth Bombyx mori is characterized by a large expansion of a single lineage of putative bitter receptors. Insect Molecular Biology 17:621-629 DOI: 10.1111/j.1365-2583.2008.00836.x.

$\mathrm{Xu}$ W, Papanicolaou A, Zhang HJ, Anderson A. 2016. Expansion of a bitter taste receptor family in a polyphagous insect herbivore. Scientific Reports 6:23666. DOI: 10.1038/srep23666.

Yan SW, Zhang J, Liu Y, Li GQ, Wang GR. 2015. An olfactory receptor from Apolygus lucorum (Meyer-Dur) mainly tuned to volatiles from flowering host plants. Journal of Insect Physiology 79:36-41 DOI: 10.1016/j.jinsphys.2015.06.002.

Yang HB, Dong JF, Sun YL, Hu ZJ, Lv QH, Li DX. 2020. Antennal transcriptome analysis and expression profiles of putative chemosensory soluble proteins in Histia rhodope Cramer (Lepidoptera:Zygaenidae). Comparative Biochemistry and Physiology Part D: Genomics and Proteomics 33:100654 DOI: 101016/jcbd2020100654.

Yang HB, Hu ZJ, Dong JF, Zhu PH, Li DX. 2019. Changes in the cold hardiness of overwintering larvae of Histia rhodope (Lepidoptera: Zygaenidae). Acta Entomology Sinica 62:979-986.

Yuvaraj JK, Andersson MN, Zhang DD, Löfstedt C. 2018. Antennal transcriptome analysis of the chemosensory gene families from trichoptera and basal Lepidoptera. Frontiers in Physiology 9:1365 DOI: 10.3389/fphys.2018.01365.

Yuvaraj JK, Corcoran JA, Andersson MN, Newcomb RD, Anderbrant O, Löfstedt C. 2017. Characterization of odorant receptors from a non-ditrysian moth, Eriocrania semipurpurella sheds light on the origin of sex pheromone receptors in Lepidoptera. Molecular Biology and Evolution 34:2733-2746 DOI: $10.1093 / \mathrm{molbev} / \mathrm{msx} 215$.

Zhang DD, Löfstedt C. 2013. Functional evolution of a multigene family: orthologous and paralogous pheromone receptor genes in the turnip moth Agrotis segetum. PLoS ONE 8:e77345 DOI: 10.1371/journal.pone.0077345.

Zhang HJ, Xu W, Chen QM, Sun LN, Anderson A, Xia QY, Papanicolaou A. 2020. A phylogenomics approach to characterizing sensory neuron membrane proteins (SNMPs) in Lepidoptera. Insect Biochemistry and Molecular Biology 118:103313 DOI: 10.1016/j.ibmb.2020.103313.

Zhang J, Bisch-Knaden S, Fandino RA, Yan SW, Obiero GF, Frosse-Wilde E, Han BS, Knaden M. 2019. The olfactory coreceptor IR8a governs larval feces mediated competition avoidance in a hawkmoth. Proceedings of the National Academy of Sciences of the United States of America 116:21828-21833 DOI: 10.1073/pnas.1913485116.

Zhang J, Liu Y, Walker WB, Dong SL, Wang GR. 2015. Identification and localization of two sensory neuron membrane proteins from Spodoptera litura (Lepidoptera:Noctuidae). Insect Science 22:399-408 DOI: 10.1111/1744-7917.12131.

Zhang YN, Jin JY, Jin R, Xia YH, Zhou JJ, Deng JY, Dong SL, 2013. Differential expression patterns in chemosensory and non-chemosensory tissues of putative chemosensory genes identified by transcriptome analysis of insect pest the purple stem borer Sesamia inferens (Walker). PLoS ONE 8:e69715 DOI:

PeerJ reviewing PDF | (2020:05:48878:1:2:NEW 21 Aug 2020) 
700

701

702

703

704

705

706

707

708

709

10.1371/journal.pone.0069715.

Zhang YN, Qian JL, Xu JW, Zhu XY, Li MY, Xu XX, Liu CX, Xue T, Sun L. 2018. Identification of chemosensory genes based on the transcriptomic analysis of six different chemosensory organs in Spodoptera exigua. Frontiers in Physiology 9:432 DOI: 10.3389/fphys.2018.00432.

Zhang YN, Zhu XY, Ma JF, Dong ZP, Xu JW, Kang K, Zhang LW. 2017. Molecular identification and expression patterns of odorant binding protein and chemosensory protein genes in Athetis lepigone (Lepidoptera:Noctuidae). PeerJ 5:e3157 DOI: 10.7717/peerj.3157.

Zheng XL, Liu JY, Zhang ZL, Wang P, Lu W. 2019. Diel rhythms of sexual behavior and pheromone responses in Phauda flammans Walker (Lepidoptera: Zygaenidae). Pest Management Science 75:30703075 DOI: $10.1002 /$ ps.5423. 


\section{Figure 1}

Heat map of FPKM values for ORs, IRs, GRs and SNMPs in male antennae (MA) and female antennae (FA).

Blue color indicates low expression, yellow color indicates moderate expression and red color indicates high expression. FA: female antennae, MA: male antennae. (A): ORs, odorant receptors, (B): IRs, ionotropic receptors, (C): GRs, gustatory receptors, (D): SNMPs, sensory neuron membrane proteins.

\begin{tabular}{|c|c|c|c|c|c|c|}
\hline $\mathbf{A}$ & FA & & FA & B & MA & FA \\
\hline HrhoOrco & & HrhoOR22 & & HrhoIR8a & & \\
\hline HrhoOR1 & & HrhoOR23 & & HrhoIR21a & & \\
\hline Hrho0R2 & & Hrho0R24 & & HrhoIR76b & & \\
\hline HrhoOR3 & & Hrho0R25 & & HrhoIR4la & & \\
\hline HrhoOR4 & & Hrho0R26 & & HrhoIR60a & & \\
\hline HrhoOR5a & & HrhoOR27 & & HrhoIR75q. & & \\
\hline HrhoOR5b & & HrhoOR28 & & HrhoIR68a & & \\
\hline HrhoOR6 & & Hrho0R29 & & HrhoIR75p & & \\
\hline HrhoOR7 & & HrhoOR30 & & HrhoIR40a & & \\
\hline HrhoOR8 & & Hrho0R31 & & & & \\
\hline HrhoOR9 & & Hrho0R32 & & C & MA & FA \\
\hline HrhoOR10 & & Hrho0R33 & & HrhoGR2 & & \\
\hline HrhoOR11 & & Hrho0R34 & & HrhoGR3 & & \\
\hline HrhoOR12 & & Hrho0R35 & & HrhoGR4 & & \\
\hline HrhoOR13 & & Hrho0R36 & & HrhoGR7 & & \\
\hline HrhoOR14 & & Hrho0R37 & & HrhoGR29 & & \\
\hline HrhoOR15 & & Hrho0R38 & & HrhoGR64a & & \\
\hline HrhoOR16 & & Hrho0R39 & & HrhoGR67 & & \\
\hline HrhoOR17 & & HrhoOR40 & & HrhoGR68. 1 & & \\
\hline HrhoOR18 & & Hrho0R41 & & & & \\
\hline HrhoOR19 & & Hrho0R42 & & D & MA & $\mathrm{FA}$ \\
\hline HrhoOR20 & & Hrho0R43 & & HrhoSNMP1 & & \\
\hline Hrho0R21 & & & & HrhoSNMP2 & & \\
\hline
\end{tabular}


Figure 2

Phylogenetic tree of putative odorant receptors (ORs).

Branch support (circles at the branch nodes) was estimated using an approximate likelihood ratio test based on the scale indicated at the bottom right. The clade of traditional PR clade is marked in yellow, the novel lineage of candidate PR clade is marked in blue and ORco in purole. 


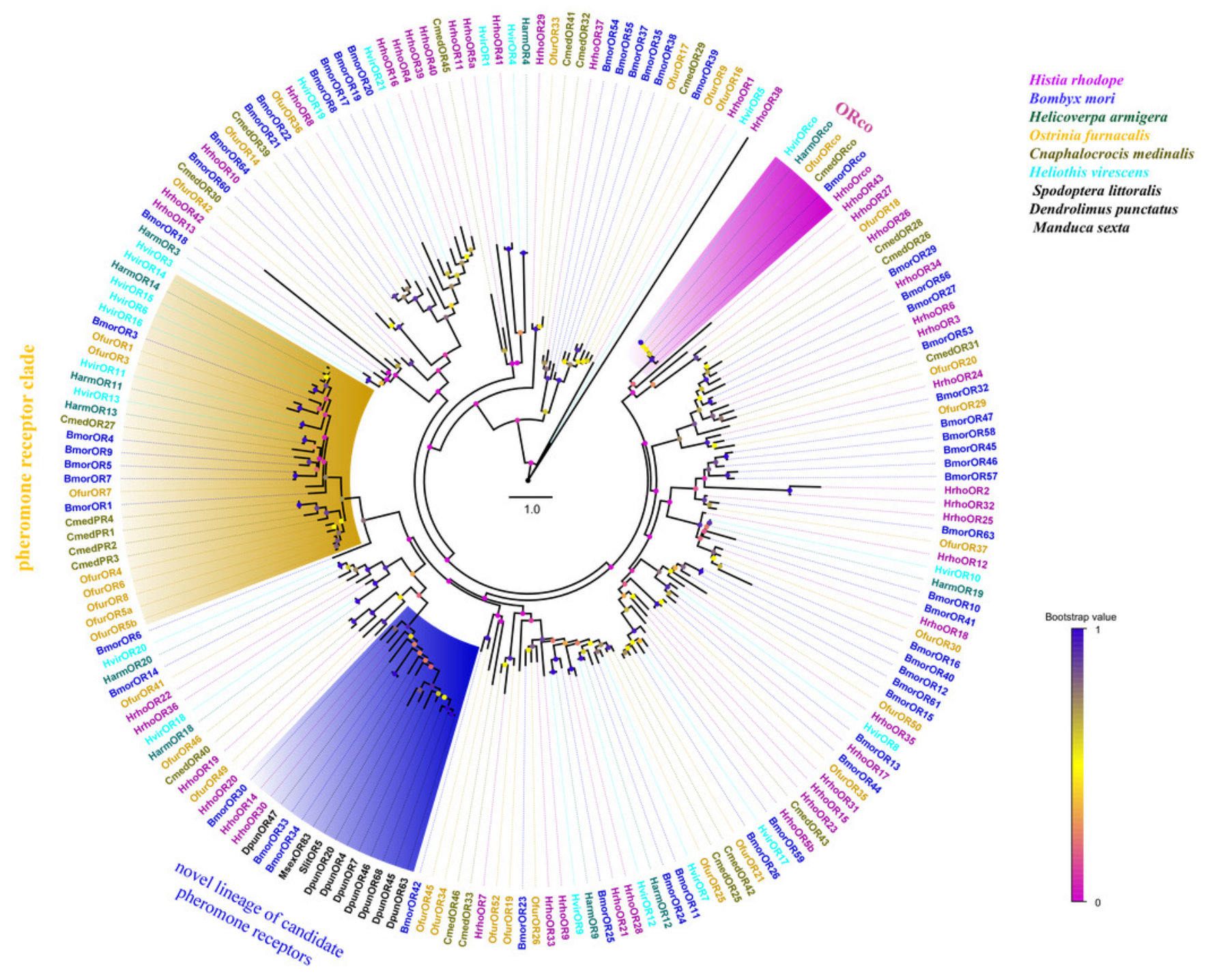




\section{Figure 3}

Phylogenetic tree of putative ionotropic receptors (IRs).

Branch support (circles at the branch nodes) was estimated using an approximate likelihood ratio test based on the scale indicated at the bottom right. Branches containing putative IR co-receptors and conversed antennal IRs are colored. 


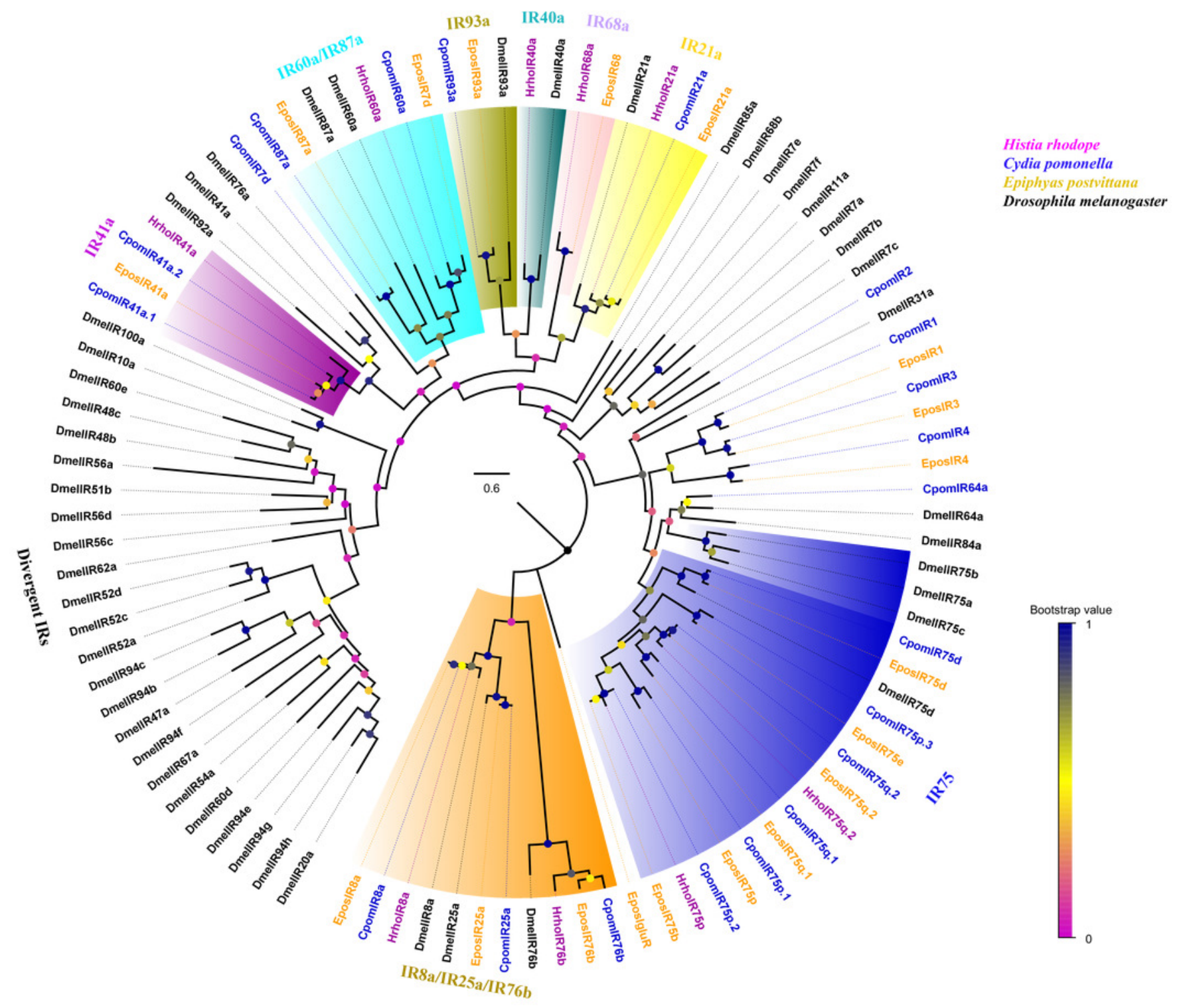




\section{Figure 4}

Phylogenetic tree of putative gustatory receptors (GRs).

Branch support (circles at the branch nodes) was estimated using an approximate likelihood ratio test based on the scale indicated at the bottom right. The sugar receptor clade, bitter receptor clade and $\mathrm{CO} 2$ receptor clade are colored.

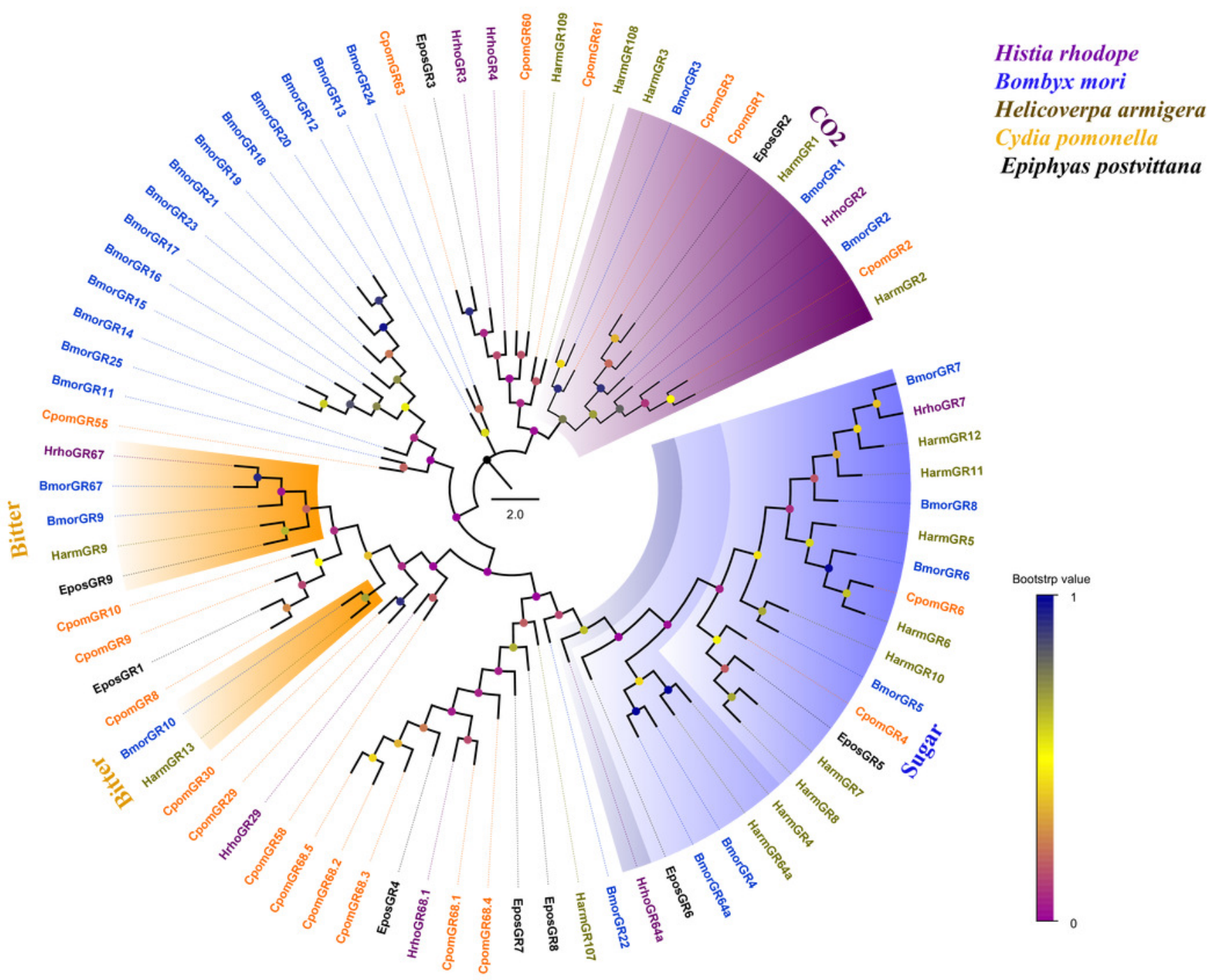




\section{Figure 5}

Phylogenetic tree of putative sensory neuron membrane proteins (SNMPs).

Branch support (circles at the branch nodes) was estimated using an approximate likelihood ratio test based on the scale indicated at the bottom right. The SNMP1 clade and SNMP2 clade are colored. 


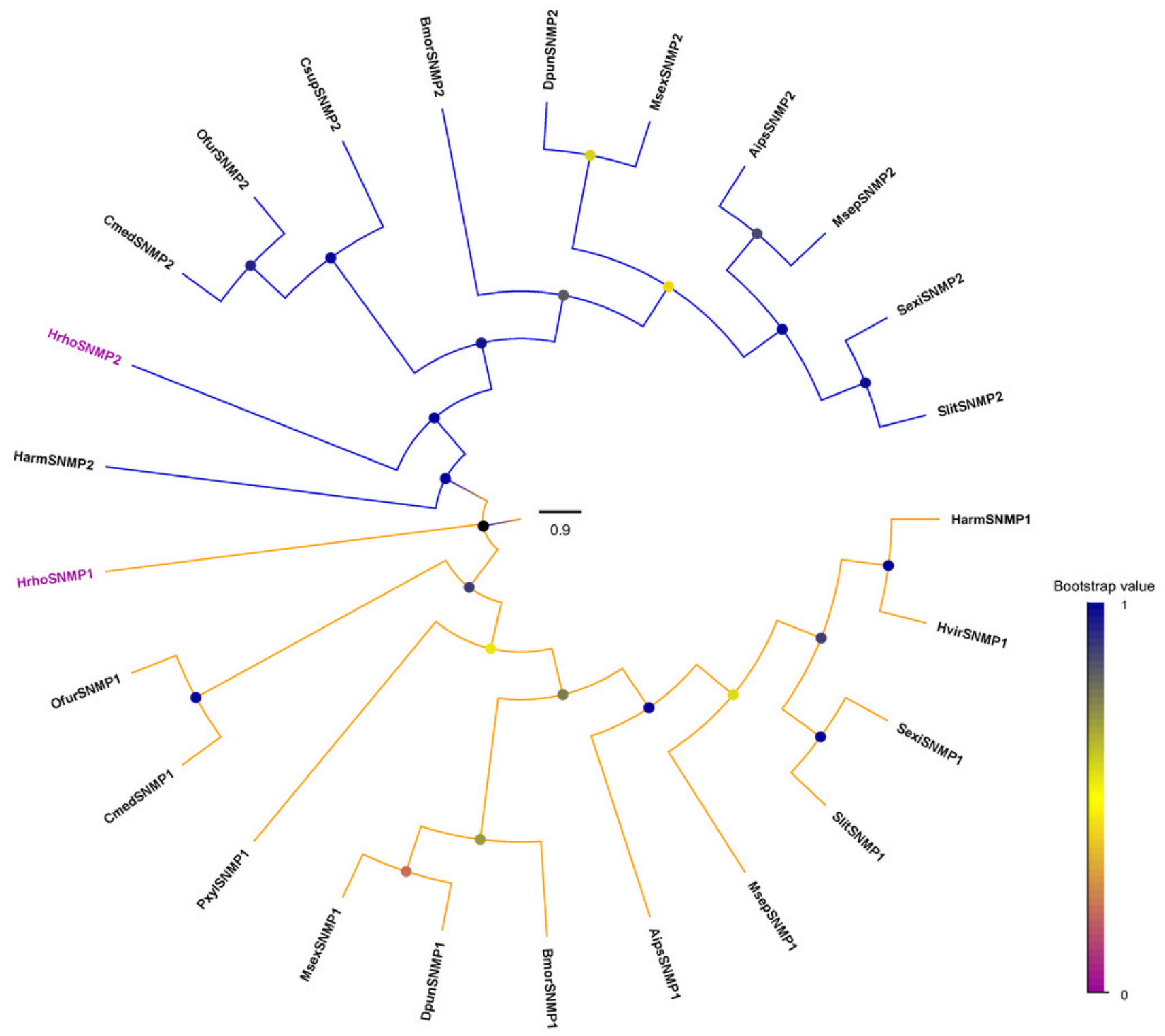




\section{Figure 6}

Relative expression levels of the chemoreceptor genes in the male antennae, female antennae, heads and legs from $H$. rhodope.

(A-J): ORs. (K-S): IRs. (T-V): GRs. (W-X): SNMPs. MA: male antennae, FA: female antennae, H: heads (without antennae), L: legs. The GAPDH was used as the reference gene, Gene expressions in various tissues are normalized relative to that in legs. Different small letters mean significant difference between tissues ( $p<0.05$, ANOVA, LSD). 

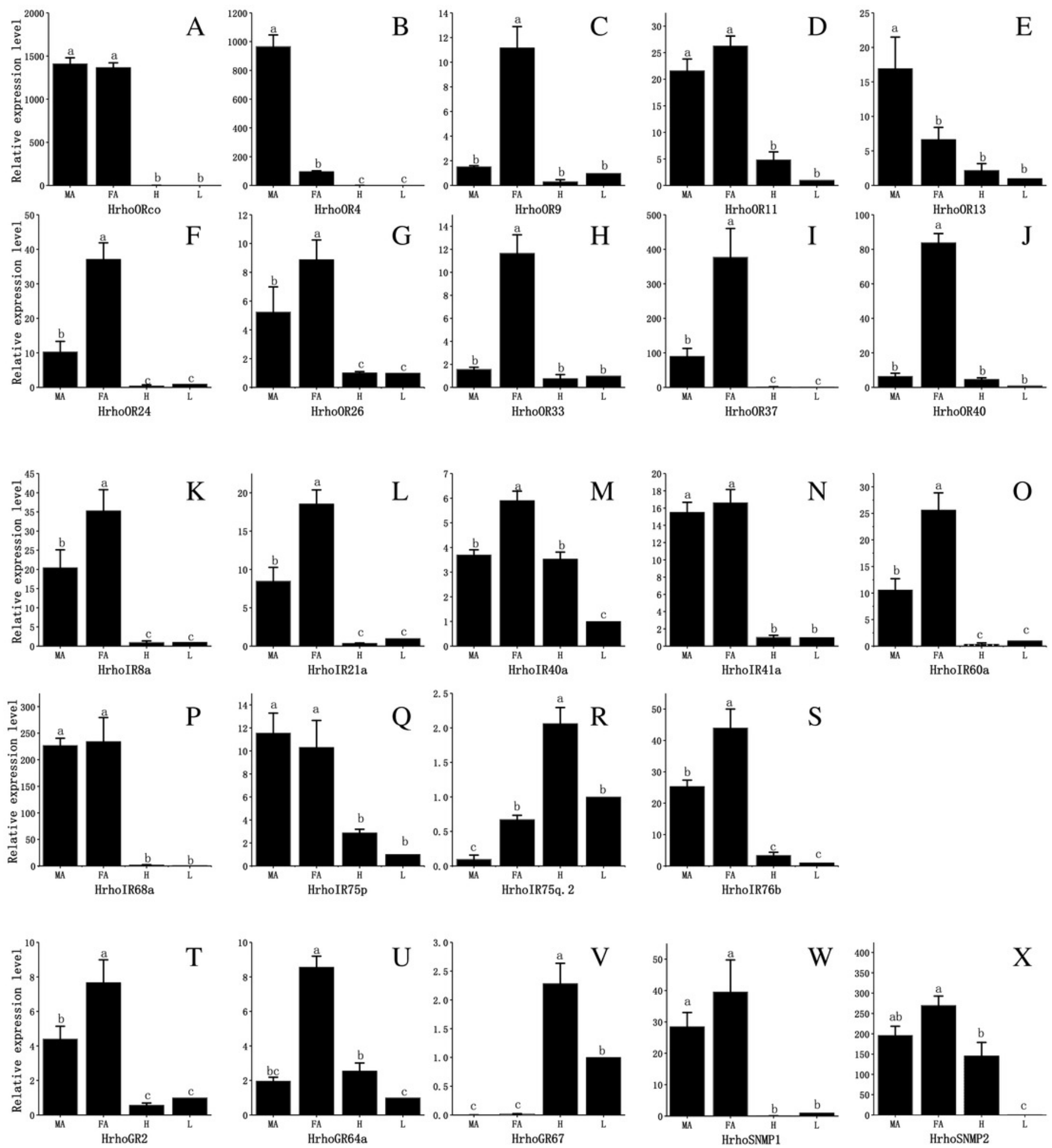


\section{Table 1 (on next page)}

The best Blast match of candidate odorant receptors (ORs) in $H$. rhodope 
Table 1 The best Blast match of candidate odorant receptors (ORs) in $H$. rhodope

\begin{tabular}{|c|c|c|c|c|c|c|c|c|}
\hline $\begin{array}{l}\text { Accession } \\
\text { number }\end{array}$ & $\begin{array}{l}\text { Gene } \\
\text { name }\end{array}$ & $\begin{array}{l}\text { ORF } \\
\text { (bp) }\end{array}$ & $\begin{array}{l}\text { Complete } \\
\text { ORF }\end{array}$ & $\begin{array}{l}\text { TMD } \\
\text { (No.) }\end{array}$ & Blastx annotation (Description/Species) & $\begin{array}{l}\text { Accession } \\
\text { number }\end{array}$ & E-value & $\begin{array}{l}\text { Identity } \\
\text { (\%) }\end{array}$ \\
\hline MN515166 & HrhoOrco & 1422 & $\mathrm{Y}$ & 7 & Orco [Galleria mellonella $]$ & QEI46859.1 & 0 & 85.44 \\
\hline MN515167 & HrhoOR1 & 687 & $\mathrm{~N}$ & 4 & olfactory receptor 11 [Ctenopseustis obliquana] & AIT71985.1 & $5.00 \mathrm{E}-40$ & 36.65 \\
\hline MN515168 & HrhoOR2 & 978 & $\mathrm{~N}$ & 6 & putative odorant receptor OR57 [Cydia nigricana] & AST36406.1 & $2.00 \mathrm{E}-57$ & 34.97 \\
\hline MN515169 & HrhoOR3 & 1215 & $\mathrm{Y}$ & 7 & odorant receptor [Eogystia hippophaecolus] & AOG12952.1 & $1.00 \mathrm{E}-149$ & 51.36 \\
\hline MN515170 & HrhoOR4 & 1203 & $\mathrm{Y}$ & 7 & olfactory receptor 66 [Ctenopseustis herana] & AIT69908.1 & $3.00 \mathrm{E}-79$ & 35.09 \\
\hline MN515171 & HrhoOR5a & 669 & $\mathrm{~N}$ & 4 & odorant receptor 94a-like isoform X2 [Manduca sexta] & XP_030035689.1 & $8.00 \mathrm{E}-47$ & 47.32 \\
\hline MN515172 & HrhoOR5b & 603 & $\mathrm{~N}$ & 2 & putative olfactory receptor 21 [Ostrinia furnacalis] & BAR43463.1 & $2.00 \mathrm{E}-86$ & 64.14 \\
\hline MN515173 & HrhoOR6 & 1212 & $\mathrm{Y}$ & 7 & putative odorant receptor OR27 [Hedya nubiferana] & AST36262.1 & 0 & 67.33 \\
\hline MN515174 & HrhoOR7 & 1224 & $\mathrm{Y}$ & 7 & odorant receptor [Eogystia hippophaecolus] & AOG12916.1 & $1.00 \mathrm{E}-135$ & 49.63 \\
\hline MN515175 & HrhoOR8 & 714 & $\mathrm{~N}$ & 3 & odorant receptor [Eogystia hippophaecolus] & AOG12915.1 & $3.00 \mathrm{E}-102$ & 63.14 \\
\hline MN515176 & HrhoOR9 & 417 & $\mathrm{~N}$ & 3 & putative odorant receptor 92a [Bombyx mandarina] & XP_028031179.1 & $1.00 \mathrm{E}-22$ & 36.96 \\
\hline MN515177 & HrhoOR10 & 1341 & $\mathrm{Y}$ & 7 & odorant receptor 1 [Cnaphalocrocis medinalis] & ALT31655.1 & 0 & 63.33 \\
\hline MN515178 & HrhoOR11 & 1185 & $\mathrm{Y}$ & 7 & odorant receptor $85 \mathrm{c}$-like [Vanessa tameamea] & XP_026493935.1 & $3.00 \mathrm{E}-88$ & 38.66 \\
\hline MN515179 & HrhoOR12 & 792 & $\mathrm{~N}$ & 6 & odorant receptor [Eogystia hippophaecolus] & AOG12948.1 & $1.00 \mathrm{E}-143$ & 74.62 \\
\hline MN515180 & HrhoOR13 & 1152 & Y & 7 & odorant receptors OR25 [Lobesia botrana] & AXF48775.1 & $1.00 \mathrm{E}-158$ & 56.49 \\
\hline MN515181 & HrhoOR14 & 1206 & Y & 7 & putative odorant receptor OR30 [Cydia pomonella $]$ & AFC91738.2 & $7.00 \mathrm{E}-122$ & 44.56 \\
\hline MN515182 & HrhoOR15 & 378 & $\mathrm{~N}$ & 3 & putative odorant receptor 57 [Conopomorpha sinensis] & AXY83406.1 & $1.00 \mathrm{E}-30$ & 47.54 \\
\hline MN515183 & HrhoOR16 & 1188 & $\mathrm{Y}$ & 7 & olfactory receptor 66 [Ctenopseustis herana] & AIT69908.1 & $2.00 \mathrm{E}-97$ & 40.54 \\
\hline MN515184 & HrhoOR17 & 1263 & Y & 7 & putative odorant receptor OR13 [Hedya nubiferana] & AST36253.1 & $9.00 \mathrm{E}-156$ & 55.81 \\
\hline MN515185 & HrhoOR18 & 1176 & $\mathrm{Y}$ & 7 & odorant receptor [Eogystia hippophaecolus] & AOG12907.1 & 0 & 67.70 \\
\hline MN515186 & HrhoOR19 & 1302 & $\mathrm{Y}$ & 7 & putative odorant receptor OR63 [Hedya nubiferana] & AST36285.1 & $1.00 \mathrm{E}-154$ & 49.07 \\
\hline MN515187 & HrhoOR20 & 951 & $\mathrm{~N}$ & 4 & odorant receptor [Eogystia hippophaecolus] & AOG12933.1 & $2.00 \mathrm{E}-119$ & 54.78 \\
\hline MN515188 & HrhoOR21 & 1233 & $\mathrm{Y}$ & 7 & olfactory receptor 11 [Ctenopseustis herana] & AIT69876.1 & $6.00 \mathrm{E}-101$ & 40.35 \\
\hline MN515189 & HrhoOR22 & 1200 & $\mathrm{Y}$ & 7 & olfactory receptor 20 [Helicoverpa armigera] & ACC63240.1 & $6.00 \mathrm{E}-121$ & 44.99 \\
\hline MN515190 & HrhoOR23 & 1110 & Y & 7 & olfactory receptor OR54 [Planotortrix octo] & AJF23812.1 & $2.00 \mathrm{E}-145$ & 54.30 \\
\hline MN515191 & HrhoOR24 & 1212 & $\mathrm{Y}$ & 7 & olfactory receptor 27 [Helicoverpa armigera] & ARF06962.1 & $8.00 \mathrm{E}-115$ & 45.18 \\
\hline MN515192 & HrhoOR25 & 1197 & $\mathrm{Y}$ & 7 & odorant receptor [Eogystia hippophaecolus] & AOG12927.1 & 0 & 71.43 \\
\hline MN515193 & HrhoOR26 & 1332 & Y & 7 & olfactory receptor 71 [Ctenopseustis herana] & AIT69911.1 & 0 & 65.08 \\
\hline MN515194 & HrhoOR27 & 378 & $\mathrm{~N}$ & 2 & olfactory receptor 37 [Carposina sasakii] & AYD42255.1 & $2.00 \mathrm{E}-42$ & 51.22 \\
\hline MN515195 & HrhoOR28 & 352 & $\mathrm{~N}$ & 2 & putative olfactory receptor 25 [Ostrinia furnacalis] & BAR43467.1 & $4.00 \mathrm{E}-22$ & 36.75 \\
\hline MN515196 & HrhoOR29 & 1230 & $\mathrm{Y}$ & 7 & odorant receptor 24a-like [Ostrinia furnacalis] & XP_028158823.1 & 0 & 71.15 \\
\hline MN515197 & HrhoOR30 & 1194 & $\mathrm{~N}$ & 6 & odorant receptor [Eogystia hippophaecolus] & AOG12934.1 & $3.00 \mathrm{E}-91$ & 36.57 \\
\hline MN515198 & HrhoOR31 & 1284 & $\mathrm{Y}$ & 7 & odorant receptor [Eogystia hippophaecolus] & AOG12926.1 & 0 & 75.93 \\
\hline MN515199 & HrhoOR32 & 927 & $\mathrm{~N}$ & 3 & putative odorant receptor OR57 [Cydia nigricana] & AST36406.1 & $3.00 \mathrm{E}-47$ & 33.00 \\
\hline MN515200 & HrhoOR33 & 756 & $\mathrm{~N}$ & 5 & olfactory receptor 14 [Heortia vitessoides] & AZB49428.1 & $7.00 \mathrm{E}-84$ & 53.57 \\
\hline MN515201 & HrhoOR34 & 1212 & Y & 7 & odorant receptors OR $29[$ Lobesia botrana $]$ & AXF48779.1 & 0 & 65.58 \\
\hline
\end{tabular}




\begin{tabular}{|c|c|c|c|c|c|c|c|c|}
\hline MN515202 & HrhoOR35 & 612 & $\mathrm{~N}$ & 3 & Olfactory receptor 23 [Manduca sexta] & CUQ99405.1 & $5.00 \mathrm{E}-64$ & 52.24 \\
\hline MN515203 & HrhoOR36 & 1218 & $\mathrm{Y}$ & 7 & odorant receptor [Eogystia hippophaecolus] & AOG12941.1 & $2.00 \mathrm{E}-134$ & 46.56 \\
\hline MN515204 & HrhoOR37 & 1143 & $\mathrm{Y}$ & 7 & olfactory receptor 32 [Cnaphalocrocis medinalis] & ANZ03145.1 & $4.00 \mathrm{E}-159$ & 56.74 \\
\hline MN515205 & HrhoOR38 & 1215 & $\mathrm{~N}$ & 0 & putative odorant receptor [Peridroma saucia] & AVF19641.1 & 0 & 67.48 \\
\hline MN515206 & HrhoOR39 & 1005 & $\mathrm{~N}$ & 6 & Olfactory receptor 65 [Manduca sexta] & CUQ99419.1 & $1.00 \mathrm{E}-69$ & 38.74 \\
\hline MN515207 & HrhoOR40 & 489 & $\mathrm{~N}$ & 3 & putative odorant receptor OR23 [Athetis lepigone] & AOE48028.1 & $3.00 \mathrm{E}-41$ & 43.90 \\
\hline MN515208 & HrhoOR41 & 1335 & $\mathrm{Y}$ & 7 & gustatory receptor $6[$ Helicoverpa armigera $]$ & ASW18695.1 & 0 & 67.59 \\
\hline MN515209 & HrhoOR42 & 720 & $\mathrm{~N}$ & 1 & $\begin{array}{l}\text { putative odorant response protein ODR-4 } \\
\text { [Danaus plexippus plexippus] }\end{array}$ & OWR50364.1 & $2.00 \mathrm{E}-144$ & 84.45 \\
\hline MN515210 & HrhoOR43 & 526 & $\mathrm{~N}$ & 3 & odorant receptor [Eogystia hippophaecolus] & AOG12949.1 & $2.00 \mathrm{E}-28$ & 37.42 \\
\hline
\end{tabular}

1

2

3

4 


\section{Table 2 (on next page)}

The best Blast match of candidate ionotrpic receptors (IRs) in $H$. rhodope 


\begin{tabular}{|c|c|c|c|c|c|c|c|c|}
\hline $\begin{array}{l}\text { Accession } \\
\text { number }\end{array}$ & $\begin{array}{l}\text { Gene } \\
\text { name }\end{array}$ & $\begin{array}{l}\text { ORF } \\
\text { (bp) }\end{array}$ & $\begin{array}{l}\text { Complete } \\
\text { ORF }\end{array}$ & $\begin{array}{l}\text { TMD } \\
\text { (No.) }\end{array}$ & Blastx annotation (Description/Species) & $\begin{array}{l}\text { Accession } \\
\text { number }\end{array}$ & E-value & $\begin{array}{l}\text { Identity } \\
(\%)\end{array}$ \\
\hline MN515211 & HrhoIR8a & 2631 & $\mathrm{~N}$ & 4 & ionotropic receptor $8 \mathrm{a}$ [Ostrinia furnacalis] & BAR64796.1 & 0 & 73.84 \\
\hline MN515212 & HrhoIR21a & 1182 & $\mathrm{~N}$ & 2 & ionotropic receptor 21a [Eogystia hippophaecolus] & AOG12851.1 & 0 & 68.77 \\
\hline MN515213 & HrhoIR76b & 693 & $\mathrm{~N}$ & 1 & putative ionotropic receptor IR76b [Cydia nigricana] & AQM73618.1 & 4E-99 & 63.22 \\
\hline MN515214 & HrhoIR41a & 1128 & $\mathrm{~N}$ & 1 & ionotropic receptor 41a [Ostrinia furnacalis] & BAR64800.1 & $2 \mathrm{E}-142$ & 56.75 \\
\hline MN515215 & HrhoIR60a & 1959 & $\mathrm{~N}$ & 3 & ionotropic receptor IR60a [Cnaphalocrocis medinalis] & APY22698.1 & 0 & 49.92 \\
\hline MN515216 & HrhoIR75q.2 & 1686 & $\mathrm{~N}$ & 3 & $\begin{array}{l}\text { putative ionotropic receptor IR75q.2 } \\
{[\text { Cydia fagiglandana }]}\end{array}$ & AST36364.1 & 0 & 62.14 \\
\hline MN515217 & HrhoIR68a & 1302 & $\mathrm{~N}$ & 4 & ionotropic receptor 68a [Eogystia hippophaecolus] & AOG12853.1 & 0 & 74.88 \\
\hline MN515218 & HrhoIR75p & 1707 & $\mathrm{~N}$ & 2 & ionotropic receptor 75a-like [Bombyx mandarina] & XP_028025288.1 & 0 & 63.46 \\
\hline MN515219 & HrhoIR40a & 1632 & $\mathrm{~N}$ & 2 & ionotropic receptor 40a [Manduca sexta] & XP 030034643.1 & 0 & 79.96 \\
\hline
\end{tabular}




\section{Table 3 (on next page)}

The best Blast match of candidate gustatory receptors (GRs) in $H$. rhodope. 
2

Table 3 The best Blast match of candidate gustatory receptors (GRs) in $H$. rhodope

\begin{tabular}{|c|c|c|c|c|c|c|c|c|}
\hline $\begin{array}{l}\text { Accession } \\
\text { number }\end{array}$ & $\begin{array}{l}\text { Gene } \\
\text { name }\end{array}$ & $\begin{array}{l}\text { ORF } \\
\text { (bp) }\end{array}$ & $\begin{array}{l}\text { Complete } \\
\text { ORF }\end{array}$ & $\begin{array}{l}\text { TMD } \\
\text { (No.) }\end{array}$ & Blastx annotation (Description/Species) & $\begin{array}{l}\text { Accession } \\
\text { number }\end{array}$ & E-value & $\begin{array}{l}\text { Identity } \\
(\%)\end{array}$ \\
\hline MN515222 & HrhoGR2 & 612 & $\mathrm{~N}$ & 4 & putative gustatory receptor GR2 [Hedya nubiferana] & AST36211.1 & 7E-116 & 88.24 \\
\hline MN515223 & HrhoGR3 & 390 & $\mathrm{~N}$ & 2 & antennal gustatory receptor 9 [Dendrolimus punctatus $]$ & ARO70281.1 & $5 \mathrm{E}-36$ & 50.38 \\
\hline MN515224 & HrhoGR4 & 198 & $\mathrm{~N}$ & 1 & antennal gustatory receptor 9 [Dendrolimus punctatus $]$ & ARO70281.1 & $7 \mathrm{E}-10$ & 55.32 \\
\hline Mn515229 & HrhoGR7 & 237 & $\mathrm{~N}$ & 1 & Gustatory receptor 7 [Operophtera brumata] & KOB71247.1 & $1 \mathrm{E}-11$ & 47.06 \\
\hline MN515225 & HrhoGR29 & 393 & $\mathrm{~N}$ & 2 & putative gustatory receptor GR29 [Cydia fagiglandana] & AST36346.1 & $1 \mathrm{E}-29$ & 45.45 \\
\hline MN515226 & HrhoGR64a & 1218 & $\mathrm{~N}$ & 5 & gustatory receptor for sugar taste 64a-like [Bombyx mandarina] & XP_028037655.1 & $7 \mathrm{E}-153$ & 53.50 \\
\hline MN515227 & HrhoGR67 & 693 & $\mathrm{~N}$ & 4 & gustatory receptor 67 [Bombyx mori] & NP_001233216.1 & $4 \mathrm{E}-48$ & 38.29 \\
\hline MN515228 & HrhoGR68.1 & 879 & $\mathrm{~N}$ & 4 & putative gustatory receptor GR68.1 [Hedya nubiferana] & AST36219.1 & 1E-43 & 34.56 \\
\hline
\end{tabular}




\section{Table 4 (on next page)}

The best Blast match of candidate sensory neuron membrane proteins (SNMPs) in $\mathrm{H}$. rhodope. 
Table 4 The best Blast match of candidate sensory neuron membrane proteins (SNMPs) in H. rhodope

\begin{tabular}{|c|c|c|c|c|c|c|c|c|}
\hline $\begin{array}{l}\text { Accession } \\
\text { number }\end{array}$ & $\begin{array}{l}\text { Gene } \\
\text { name }\end{array}$ & $\begin{array}{l}\text { ORF } \\
\text { (bp) }\end{array}$ & $\begin{array}{l}\text { Complete } \\
\text { ORF }\end{array}$ & $\begin{array}{l}\text { TMD } \\
\text { (No.) }\end{array}$ & Blastx annotation (Description/Species) & $\begin{array}{l}\text { Accession } \\
\text { number }\end{array}$ & E-value & $\begin{array}{l}\text { Identity } \\
(\%)\end{array}$ \\
\hline MN515220 & HrhoSNMP1 & 1581 & $\mathrm{Y}$ & 2 & Sensory neuron membrane protein 1 [Papilio xuthus] & KPI90909.1 & 0 & 66.22 \\
\hline MN515221 & HrhoSNMP2 & 1422 & $\mathrm{Y}$ & 1 & Sensory neuron membrane protein 2 [Ostrinia nubilalis] & E5EZW9.1 & 0 & 64.08 \\
\hline \multicolumn{9}{|l|}{1} \\
\hline \multicolumn{9}{|l|}{2} \\
\hline \multicolumn{9}{|c|}{3} \\
\hline & & & & & & & & \\
\hline
\end{tabular}

